\title{
Yabancı Dil Olarak Farsça Öğrenen Türk Öğrenicilerin Yazılı Anlatım Hataları: Sözlüksel-Anlamsal Hatalar
}

\section{Written Expression Errors of Turkish Students Studying Persian as a Foreign Language: Lexico-Semantic Errors}

\author{
Ümit GEDİK ${ }^{1}$ (1)
}

*Bu çalışma "Yabancı Dil Olarak Farsça Öğrenen Türk Öğrenicilerin Yazılı Anlatımlarının Hata Çözümlemesi Yöntemine Göre Değerlendirilmesi" başılıkı doktora tezinden üretilmiştir.

'Karamanoğlu Mehmetbey Üniversitesi, Yabancı Diller Yüksekokulu, Mütercim-Tercümanlık Bölümü, Farsça Mütercim-Tercümanlık Anabilim Dalı, Karaman, Türkiye

\section{ORCID: Ü.G. 0000-0001-5624-1776}

Sorumlu yazar/Corresponding author: Ümit GEDIK (Dr.),

Karamanoğlu Mehmetbey Üniversitesi, Yabancı Diller Yüksekokulu, Mütercim-Tercümanlık Bölümü, Farsça Mütercim-Tercümanlık Anabilim

Dalı, Karaman, Türkiye

E-posta: ugedik@kmu.edu.tr

Başvuru/Submitted: 07.11.2020 Revizyon Talebi/Revision Requested: 26.11.2020

Son Revizyon/Last Revision Received: 19.12.2020

Kabul/Accepted: 20.12 .2020

Atıf/Citation: Gedik, Umit. "Yabancı Dil Olarak Farsça Öğrenen Türk Öğrenicilerin Yazılı Anlatım Hataları: Sözlüksel-Anlamsal Hatalar". Şarkiyat Mecmuası - Journal of Oriental Studies 38 (2021), 137-161.

https://doi.org/10.26650/jos.822836

\section{ÖZ}

Bu araştırmanın amacı; yabancı dil olarak Farsça öğrenen Türk öğrenicilerin sözlüksel ve anlamsal yazılı anlatım hatalarını hata çözümlemesi yöntemine göre değerlendirmek, hata oranları dağılımına ilişkin frekans ve yüzde dağılımlarını belirlemek ve elde edilen veriler ve hata yığılımları doğrultusunda yabancı dil olarak Farsça öğretimi için uygun önerilerde bulunmaktır. Araştırmada, betimsel tarama modeline uygun biçimde taranan veriler, nitel araştırma yöntemlerinden içerik analizi tekniği kullanılarak çözümlenmiş̧ir. Araştırmanın çalışma grubunu, tamamının anadilleri Türkçe olan Ankara Üniversitesi Dil ve Tarih-Coğrafya Fakültesi Doğu Dilleri ve Edebiyatları Bölümü, Fars Dili ve Edebiyatı Anabilim Dalı'nda öğrenim gören 58 kadın, 23 erkek toplam 81 öğrenici oluşturmuştur. Araştırmanın verileri, öğrenicilerin 2017-2018 Eğitim-Öğretim yılının güz ve bahar dönemlerindeki yazılı anlatımlarına veri oluşturan çeşitli derslerinin ara sınav ve yarıyıl sonu sınavları ve öğreticiler tarafından ders dönemlerinde öğrenicilere vermiş oldukları ödevlerden elde edilmiştir. Elde edilen bu veriler, sözlüksel-anlamsal hatalar grubu altında sınıflandırılmış ve çözümlenmiştir. Yapılan çözümlemeler sonucunda, yabancı dil olarak Farsça öğrenen Türk öğrenicilerin sözlüksel-anlamsal hata grubunda yer alan yazılı anlatımlarında toplam 85 hata tespit edilmiştir. Dağılımları dikkate alındığında, bu hataların 56 hata frekansı ve $\% 66^{\prime}$ 'ık oranla diliçi ya da gelişimsel hatalar, 29 hata frekansı ve \%34'lük oranla dillerarası aktarım, Türkçe sözcük seçimi hataları olduğu saptanmıştı. Araştırmadan elde edilen bu nicel sonuçlar doğrultusunda yabancı dil olarak Farsça öğrenen Türk öğrenicilerin yazılı anlatım becerilerindeki sözlüksel-anlamsal hataların en aza indirilebilmesi adına çözüm önerilerinde bulunulmuştur.

Anahtar kelimeler: Farsça, Türklere Farsça Öğretimi, Hata Çözümlemesi, Sözlüksel-Anlamsal Hatalar

\section{ABSTRACT}

This study aimed to evaluate the written expression inaccuracies of Turkish learners studying Persian as a foreign language. Employing error analysis, this research attempted to determine the frequency and percentage distributions of error rates and make practical suggestions for teaching Persian as a foreign language in accordance with the obtained data and error heaps. A descriptive survey model was adopted, and data scanning was carried out via qualitative 
content analysis. The research sample consisted of 81 Turkish students, 58 female and 23 male studying at Ankara University, Faculty of Languages, History and Geography and Department of Oriental Languages and Literatures, Department of Persian Language and Literature. Data were obtained from the learners midterm and final examinations and assignments given by their instructors during the fall and spring semesters of the academic year 2017-18. The obtained data were classified into one basic error group according to their characteristics and analyzed under the headings of lexico-semantic errors. A total of 85 errors were identified in the participants' written expressions, 56 which were intralingual errors $66 \%$ and 29 were interlingual and Turkish word selection errors $34 \%$. In line with these results solutions were suggested to minimize the mistakes in written expression committed by Turkish learners.

Keywords: Persian, Teaching Persian to Turkish, Error Analysis, Lexico-Semantic Errors

\section{EXTENDED ABSTRACT}

The current expansion of international relations has required nations to communicate in their native languages as well as learn the languages of other countries. In Turkey, Persian has been a source of interest in education and various fields, such as history, literature, and religion, for several years. The importance of such a situation is currently immense in terms of developing relations with a geography previously dominated by the Persian language and countries where it is spoken as a mother tongue.

Despite the significance of Persian in Turkey, a realistic solution has yet to be devised to address the problems and difficulties encountered while teaching Persian as a foreign language in the country. Hence, one cannot deny the need for a curriculum supported by scientific research and contemporary teaching methods and techniques in teaching Persian as a foreign language as well as for educational materials for Turkish learners of Persian.

During their learning process, Turkish learners studying Persian as a foreign language commit various error strings regarding the Persian language structure. Their difficulties while learning Persian have both similarities and differences in terms of linguistic features. Therefore, Persian teachers must develop specific teaching methods and prepare materials that are specific to these learners. In addition, teachers must consider these students' difficulties in their Persian learning process. Teachers must also be able to predict the kind of difficulties and mistakes. That could be committed by Turkish learners studying Persian as a foreign language and improve the efficiency of their teaching process for these students.

However, no studies have been conducted on teaching Persian as a foreign language in Turkey. Therefore, this study's purpose, which is to evaluate the written expression errors of Turkish students learning Persian as a foreign language via error analysis, will be crucial in advancing the Persian language. This study will also serve as a teaching and learning resource for teachers and learners of this language, respectively.

As mentioned above, Turkish learners encounter several difficulties during their education process, from which various problems emerge. One such issue entails errors in written expressions. This study aimed to determine Turkish learners' lexico-semantic errors and suggest appropriate solutions in line with the obtained data. Data were scanned in accordance 
with the descriptive survey model and examined using qualitative content analysis. The study sample consisted of 81 Turkish students (58 female and 23 male) studying at Ankara University's Faculty of Languages, History, and Geography; Department of Oriental Languages and Literatures; and Department of Persian Language and Literature. This study assumed that these learners have already learned Persian sentence structures and grammatical forms and have taken examinations and written essays during the lessons based on their acquired knowledge. The study was conducted in the fall and spring semesters of the 2017-18 academic year, over a period of $14+14$ weeks. Data collection tools were limited to FAR119 Persian Grammar I (Basic Level), FAR115 Dictation and Written Expression, FAR201 Persian Grammar III (Advanced), FAR215 Turkish to Persian Translation, FAR413 Composition, FAR102 Persian Grammar II (Intermediate Level), FAR116 Translation of Persian to Turkish Language, FAR11t Translation of Turkish to Persian Language, and FAR214 Persian Composition courses, as well as the midterm and final examinations and homework given by instructors during this period. In addition, personal information forms were used to determine the learners' demographic characteristics.

The results detected a total of 85 errors under the lexico-semantic category. The data further showed 56 linguistic or developmental errors (66\%), which is more than the 29-interlanguage transmission/Turkish word selection errors (34\%). Turkish word selection errors emerged because the learners did not know the necessary Persian lexicon for their written expressions and instead used Turkish words. Hence, Turkish learners studying Persian as a foreign language committed negative-transfer errors in their written expressions. These learners showed an insufficient command of words in the Persian lexicon and inadequate vocabulary.

Overall, Turkish students learning Persian as a foreign language face difficulty in written expressions and commit simple mistakes in their compliance with their language levels. Thus, for the lexico-semantic error group, subtleties in the meanings of Persian words would need to be considered, and the methods for word teaching need to be reviewed. This means that more efficient teaching methods in the Persian language learning process need to be prioritized. 


\section{Giriş}

Günümüzde artış gösteren uluslararası ilişkiler, ulusların kendi anadilleri ile iletişim kurmalarını yetersiz kılarken, ulusların farklı ülkelerin dillerini öğrenmelerini zorunlu bir ihtiyaç haline getirmektedir. Farsça, ülkemizde uzun yıllar boyunca edebiyat, tarih, kültür, ticaret ve uluslararası ilişkiler gibi birçok alanda öğrenim ve öğretimine ilgi gösterilen kaynak diller arasında yer almıştır. Bu durum gerek geçmişte Farsçanın hâkim olduğu coğrafya, gerekse günümüzde anadili olarak konuşulduğu ülkelerle ilişkilerin geliştirilmesi bakımından büyük bir önem arz etmektedir. Farsçanın sahip olduğu bu öneme karşın, ülkemizde Farsçanın yabancı dil olarak öğretiminde karşılaşılan sorunlara ve güçlüklere gerçekçi bir çözüm önerisi henüz getirilememektedir. Sorunun önemi, Farsçayı yabancı dil olarak öğreten öğreticiler tarafından fark edilmiş olmasına rağmen, karşılaşılan güçlüklerin ortadan kaldırılması için gerekli çalışmaların yapılmadığ 1 görülmektedir.

Bu gerçekler 1şığında, ülkemizde bilimsel araştırma yöntemleri ile Farsçanın yabancı dil olarak öğretimi alanında çağdaş öğretim yöntem ve teknikleri ile hazırlanacak bir öğretim programına ihtiyaç duyulmaktadır. Kuşkusuz bütün dillerin kendilerine özgü dil yapıları bulunduğu gibi Farsçanın da kendine özgü bir dil yapısı bulunmaktadır. Anadili Türkçe olan öğreniciler hedef dil olan Farsçayı öğrenirken çeşitli güçlüklerle karşılaşmaktadırlar. Öğreniciler farklı yazımsal ${ }^{1}$, sözlüksel-anlamsal ${ }^{2}$, dilbilgisel ${ }^{3}$ hatalar yapmakta ve bu sebeple ya dillerarası aktarım hataları yani kendi anadilleri olan Türkçeden olumsuz aktarımlarda bulunmakta ya da diliçi, gelişimsel hatalar yapmaktadırlar. Türk öğrenicilerin Farsçayı öğrenirken karşılaştıkları güçlükler, üretmiş oldukları hatalı yapılar ve geliştirdikleri hatalı kavramlar dilbilimsel açıdan benzer ya da farklı özellikler taşımaktadır. Bu nedenle, yabancı dil olarak Farsça öğreticileri, Türk öğrenicilerin Farsça öğrenimlerindeki öğrenim güçlüklerini göz önünde bulundurarak öğrenicilere özgü öğretim yöntemleri geliştirmeli ve bu öğrenicilere özgü araç-gereçler hazırlamalıdırlar. Bunun için hedef dil Farsçayı yabancı dil olarak öğrenen Türk öğrenicilerin öğretim süreçlerinde ne tür zorluklar yaşadıkları ne tür hatalar yaptıkları öğreticiler tarafından önceden kestirilebilmeli ve bu doğrultuda öğretim süreçleri bu öğreniciler için daha verimli bir hale getirilmelidir.

\section{1. Çalışmanın Ámacı}

Uzun yıllardır ülkemizde öğretimi yapılan Farsçanın farklı sebepler ile öğrenilmek istenen bir yabancı dil haline gelmesi, Farsçanın yabancı dil olarak öğretimi ile ilgili akademik çalışmaların yapılmasını zorunlu hale getirmiştir. Bu zorunluluk dikkate alındığında Türkiye'deki Farsça öğrenicilerin öğrenim süresi boyunca karşılaştıkları zorluklar ve bu zorluklar ile ortaya çıkan çeşitli sorunlar neticesinde ne gibi hatalar yaptıklarına dair herhangi bir araştırmanın yapılmadığı görülmektedir. Bu önem doğrultusunda araştırmada, yabancı dil olarak Farsça

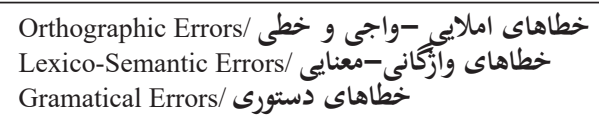


öğrenen Türk öğrenicilerin yazılı anlatımlarında yaptıkları hataların belirlenmesi, bu hataların yazımsal hata türleri sınıflandırması içerisinde yer alan alt başlıklarından Sözlüksel-Anlamsal hata türü içerisinde incelenmesi ve elde edilen veriler doğrultusunda uygun çözüm yolları önerilmesi amaçlanmaktadır.

\section{2. Çalışmanın Önemi}

Ülkemizde Farsçanın yabancı dil olarak öğretimi yıllardır devam etmesine rağmen, öğretimde kullanılan yöntemler bazı farklılıklar ile neredeyse benzerlikler göstermektedir. Bununla birlikte uygulamalı dilbilimde ve yabancı dil öğretim yöntemlerinde ortaya çıkan gelişmeler Farsça öğretiminde de yeni arayışları beraberinde getirmektedir. Bu nedenle araştırmada uygulanacak hata çözümlemelerinin, Türkiye' de uzun yıllardır yabancı dil olarak öğretimi yapılan Fars dilinin öğretici ve öğrenicilerine kaynaklık etmesi açısından kayda değer bir öneme sahip olduğu düşünülmektedir. Bu amaçla çalışmada “Anadili Türkçe olan öğrenicilerin yabancı dil olarak Farsça öğrenirken yazılı anlatım süreçlerinde yaptıkları hatalar dilsel özellikleri bakımından nasıl bir dağılım göstermektedir? Yabancı dil olarak Farsça öğrenen Türk öğrenicilerin yazılı anlatım süreçlerinde yaptıkları sözlüksel-anlamsal hatalar nelerdir? sorularına yanıt aranmıştır.

\section{3. Çalışmanın Yöntemi}

Çalışmada, yabancı dil olarak Farsça öğrenen Türk öğrenicilerin Farsça yazılı anlatımlarındaki sözlüksel-anlamsal alt hata türünde yapmış oldukları hatalar, günümüze kadar uygulamalı dilbilimde etkili olmuş ve yabancı dil öğretimine katkıları bakımından birbirini tamamlayan Karşıtsal Çözümleme ve Hata Çözümlemesi araştırma yöntemlerinden faydalanılarak analiz edilmiştir. Araştırmada elde edilen veriler, Karasar' 'n “Tarama modelleri, geçmişte ya da halen var olan bir durumu var olduğu şekli ile betimlemeyi amaçlayan araştırma yaklaşımlarıdır. Araştırmaya konu olan olay ya da nesne, kendi koşulları içinde ve olduğu gibi tanımlanmaya çalışılır. Onları, herhangi bir şekilde değiştirme, etkileme çabası gösterilmez. Bilinmek istenen şey vardır ve oradadır. Önemli olan, onu uygun bir biçimde gözleyip belirleyebilmektir" olarak açıkladığı 'betimsel tarama modeli'ne ${ }^{4}$ uygun bir biçimde taranmış ve Büyüköztürk'ün "İçerik analizi, belirli kurallara dayalı kodlamalar ile bir metnin bazı sözcüklerinin daha küçük içerik kategorileri ile özetlendiği sistematik, yinelenebilir bir teknik olarak tanımlanır" olarak belirttiği, nitel araştırma yöntemlerinden 'içerik analizi tekniği ${ }^{5}$ kullanılarak gerçekleştirilmiştir.

\section{4. Çalıșmanın Ön Kabulleri}

Çalışmada, öğrenicilerin Farsça cümle yapılarını ve dilbilgisel biçimleri daha önce öğrenmiş oldukları varsayılmıştır.

4 Niyazi Karasar, Bilimsel Araştırma Yöntemi, Ankara: Nobel Yayın Dağıtım, 2010, s.77.

5 Şener Büyüköztürk vd. Bilimsel Araştırma Yöntemleri (Geliştirilmiş 11. Baskl), Ankara: Pegem Akademi, 2013, s. 240 . 
Öğreniciler sınav kâğıtlarını ve dersler süresince yazmış oldukları kompozisyonları var olan bilgilerine dayalı olarak cevaplamışlardır.

\section{5. Çalışmanın Grubu ve Sınırlılıkları}

Simith’e göre: “Çalışma grubu, ulaşılabilen bir gruptur. Araştırmacının ya doğrudan gözleyerek ya da ondan seçilmiş bir örnek küme üzerinde yapılan gözlemlerden yararlanarak, hakkında görüş bildirebileceği evren çalışma evrenidir. Pratikte, araştırmalar çalışma grubu üzerinde yapılmakta olup sonuçların da yalnızca bu sınırlı grubu genellenmesi kaçınılmazdır". ${ }^{6}$ Bu bağlamda "Yabancı Dil Olarak Farsça Öğrenen Türk Öğrenicilerin Yazılı Anlatım Hataları: Sözlüksel-Anlamsal Hatalar” başlıklı araştırmanın çalışma gurubunu, Ankara Üniversitesi Dil ve Tarih-Coğrafya Fakültesi Doğu Dilleri ve Edebiyatları Bölümü, Fars Dili ve Edebiyatı Anabilim Dalı'nda öğrenim gören 58 kadın, 23 erkek toplam 81 öğrenici oluşturmaktadır.

Çalışma, 2017-2018 Eğitim-Öğretim yılının güz ve bahar dönemlerinde 14+14 haftalık bir süreçte gerçekleştirilmiştir. Veri toplama araçları, öğrenicilerin demografik özelliklerini tespit etmek amacıyla kullanılan kişisel bilgi formu ve yazılı anlatımlarına veri oluşturacak güz ve bahar dönemlerinde okutulan; FAR119 Farsça Dilbilgisi I (Temel Düzey), FAR115 Farsça Dikte ve Yazılı Anlatım, FAR201 Farsça Dilbilgisi III (İleri Düzey), FAR215 Türkçeden Farsçaya Çeviri, FAR413 Kompozisyon, FAR102 Farsça Dilbilgisi II (Orta Düzey), FAR116 Farsçadan Türkçeye Çeviri, FAR202 Farsça Dilbilgisi IV (Yüksek Düzey), FAR214 Farsça Kompozisyon derslerinin ara sınav ve yarıyıl sonu sınavları ve öğreticiler tarafından ders dönemlerinde öğrenicilere verilen ödevler ile sınırlandırılmıştır.

\section{Araştırmaya Katılan Öğrenicilerin Demografik Özelliklerine ilişkin Bilgiler}

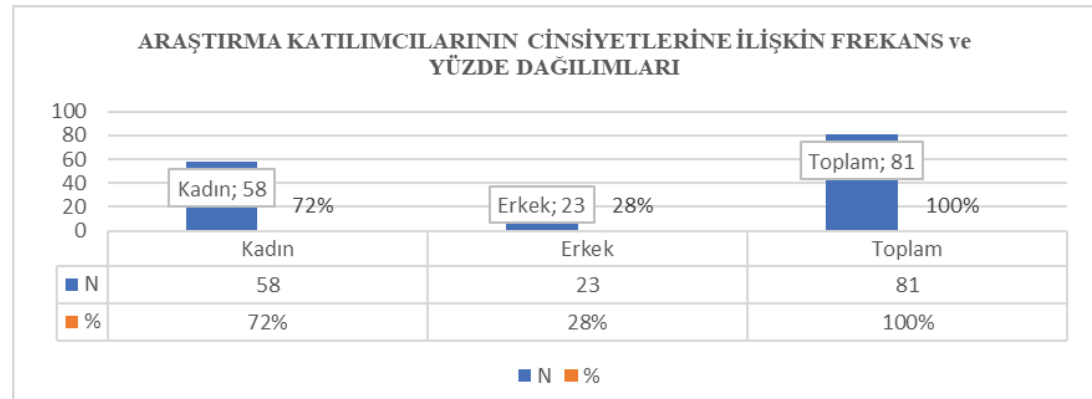

Grafik 1. Araştırma Katılımcılarının Cinsiyetlerine İlişskin Frekans ve Yüzde Dağılımları

Grafik 1'e bakıldığında araştırmaya katılan toplam 81 öğrenicinin 58'inin \%72'lik bir oranla kadın, 23’ünün \%28'lik oranla erkek katılımcılar olduğu görülmektedir.

6 Niyazi Karasar, Bilimsel Araştırma Yöntemi, s.77. 


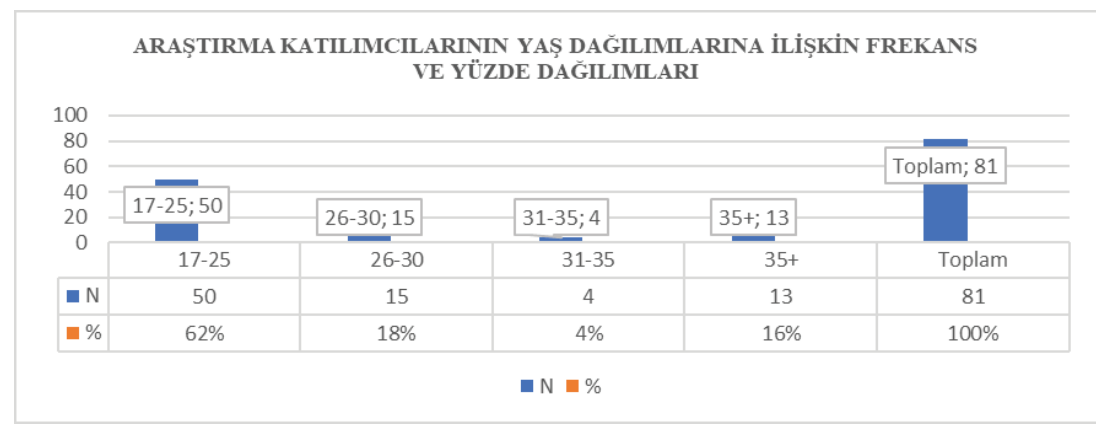

Grafik 2. Araştırma Katılımcılarının Yaş Dağılımlarına İlişkin Frekans ve Yüzde Dağılımları

Grafik 2'ye bakıldığında araştırmaya katılan öğrenicilerin 50'sinin \%62'lik bir oranla 17-25 yaş aralığında, 15'inin \% 18'lik bir oranla 26-30 yaş aralığında, 3'ünün \%4'lük bir oranla 31-35 yaş aralığında ve 13'ünün \%16'lık bir oranla 35+ yaş ve üzerinde olduğu görülmektedir. Bu oranlar dikkate alındığında araştırmaya katılan öğrenicilerin \%62'sinin ülkemizde üniversite okuma yaş aralığı olan (17-25) yaş aralığında olması bize bu öğrenicilerin Farsçayı akademik amaç doğrultusunda öğrendiklerine yönelik çıkarımda bulunma imkânı vermektedir.

\subsection{Hata Çözümlemesi Yöntemi}

Yabancı dil öğrenim sürecinde hedef dili öğrenen öğrenicilerde bilgi eksikliğinden ya da yetersiz öğrenimden kaynaklı dizgesel sapmalar oluşmakta ve bu sapmalar sonucu hatalar ortaya çıkmaktadır. ${ }^{7}$ Ellis'e göre; öğreniciler açısından devingen olan dilbilgisi kalıcı değildir. Öğreniciler dilbilgisini kurallar ekleyerek, silerek ve tüm dizgeyi yeniden yapılandırarak sürekli değiştirmektedir. Bu süreçte, öğreniciler dilbilgisi kurallarını eklediklerinde, sildiklerinde ya da yeniden yapılandırdıklarında hedef dile ait hatalar oluşturmaktadırlar. ${ }^{8}$

Zaman içerisinde dilbilimciler tarafından ortaya atılan farklı görüşler, öğreniciler tarafından yapılan bütün hataların aktarım ya da anadili girişimi ile açıklanamayacağına ve bu hataların tanımlanabilmesi için yabancı dil öğrenicilerinden elde edilecek verilere dayanan hata çözümlemesi yönteminin bir alternatif olarak görülebileceğini dile getirmişlerdir. Bu çerçevede karşıtsal çözümleme, anadili ve öğrenilecek hedef dili karşıtsal bir biçimde açıklayarak, öğrenicinin hedef dili edinimi sürecinde karşılaşabileceği zorluklara ilişkin kestirmelerde bulunurken hata çözümlemesi, hedef dili öğrenen öğrenicilerden elde edeceği verilere dayanarak öğrenicilerin yaşayacakları zorlukları belirlemeye çalışmaktadır. ${ }^{9}$

7 Gökhan Çetinkaya, "Yanlış Çözümlemesi: Yabancı Dil Olarak Türkçe Öğrenen B2 Düzeyindeki Öğrencilerin Yazılı Metinlerine İlişkin Görünümler”, International Journal of Languages Education and Teaching, Volume 3/1 April (2015): s.165.

8 Rod Ellis, Second Language Acquisition. Oxford: Oxford University Press, 1997, s.35.

9 Emrullah İşler, "Karşıtsal Çözümleme ve Arapça Öğretimi”, Nüsha, Yı1:2, Sayı:6, (2002), s.127; K. Kaan Büyükikiz ve Sevil Hasırcı, "Yabancı Dil Olarak Türkçe Öğrenen Öğrencilerin Yazılı Anlatımlarının Yanlış Çözümleme Yaklaşımına Göre Değerlendirilmesi, Ana Dili Eğitim Dergisi, Sayı:1(4), (2013), s. 53. 
Hata çözümlemesi yöntemi yabancı dil öğretiminde 1960’lı yıllarda Stephen Corder ve arkadaşları tarafından ortaya atılmıştır. Bu yöntem, dilin nasıl öğrenildiği ve öğrenicinin dil öğrenirken nasıl bir strateji uyguladığı ile ilgili kanıtlar sunmaktadır. ${ }^{10}$ Hata çözümlemesi yöntemi hedef dili öğrenen öğrenicilerden alınacak olan verilerdeki, bu veriler genellikle hedef dilde belirli bir konu hakkında yazılacak kompozisyon ya da uygulanmış olan sınav kağıtlarından elde edilecek veriler olup, hataların belirlenip çeşitli başlıklar altında sınıflandırılması ve yorumlanması biçimiyle gerçekleşmektedir.

Elbette hata çözümlemesi yöntemi belirli sınırlılıklar ve düzen içerisinde yapılmaktadır. Bazı araştırmacıların, bu sınırlılık ve düzen için belirledikleri hata çözümleme aşamaları şu şekildedir:

Sridhar, hata çözümlemesinde kullanılacak yöntemi şu şekilde sıralamaktadır:

a. Verilerin toplanmasi

b. Hataların belirlenmesi

c. Hata türlerinin sınıflandırılması

d. Hata türlerinin görecelik sıklık tablosu

e. Hedef dildeki zorluk alanlarının belirlenmesi

f. İyileştirme çalışmaları (iyileştirici programlar, dersler, araç-gereçler, etkinlikler vb.) ${ }^{11}$

Corder ise hata çözümleme yönteminin aşamalarını beş başlık altında sıralamıştır:

a. Hedef dil verilerinin toplanması

b. Hataların belirlenmesi

c. Hataların tanımlanması

d. Hataların açıklanması

e. Hataların değerlendirilmesi ${ }^{12}$

Bayraktaroğlu'na göre karşıtsal çözümleme ve hata çözümlemesinin yabanc1 dil öğretiminde uygulanışı aşağıdaki tablo doğrultusunda yapılmalıdır: ${ }^{13}$

10 Stephen Corder, "The Significance of Learners Error", International Review of Applied Linguistics, Say1:5, (1967), s.167; Fatih Yılmaz ve Derya Bircan. "Türkçe Öğretim Merkezinde Okuyan Yabancı Öğrencilerin Yazılı Kompozisyonlarının "Yanlış Çözümleme Yöntemi”ne Göre Değerlendirilmesi”, International Journal of Language Academy, Volume 3/1 Spring, (2015). s.116.

11 Shikaripur N Sridhar, "Contrastive Analysis, Error Analysis and Interlanguage". Reading English as a Second Language. Ed. Kenneth Croft. USA: Winthrop Publisher Inc., 1976, s. 268; Büyükikiz ve Hasırc1, "Yabancı Dil Olarak Türkçe Öğrenen Öğrencilerin Yazılı Anlatımlarının Yanlış Çözümleme Yaklaşımına Göre Değerlendirilmesi, s.55.

12 Yılmaz ve Bircan, "Türkçe Öğretim Merkezinde Okuyan Yabancı Öğrencilerin Yazılı Kompozisyonlarının "Yanlış Çözümleme Yöntemi”ne Göre Değerlendirilmesi", s.117.

13 Emrah Boylu, Esma Zeynep Güney ve Kevser Esma Özyalçın, "Yanlış Çözümleme Yaklaşımına Göre Türkçeyi Yabancı Dil Olarak Öğrenen B1 Seviyesi Öğrencilerinin Yazılı Anlatımlarının Değerlendirilmesi”, International Journal of Languages Education and Teaching, Volume 5, Issue 3, September, (2017), s.190 
Tablo 1. Karşıtsal Çözümleme ve Hata Çözümlemesinin Yabancı Dil Öğretiminde Uygulanış1

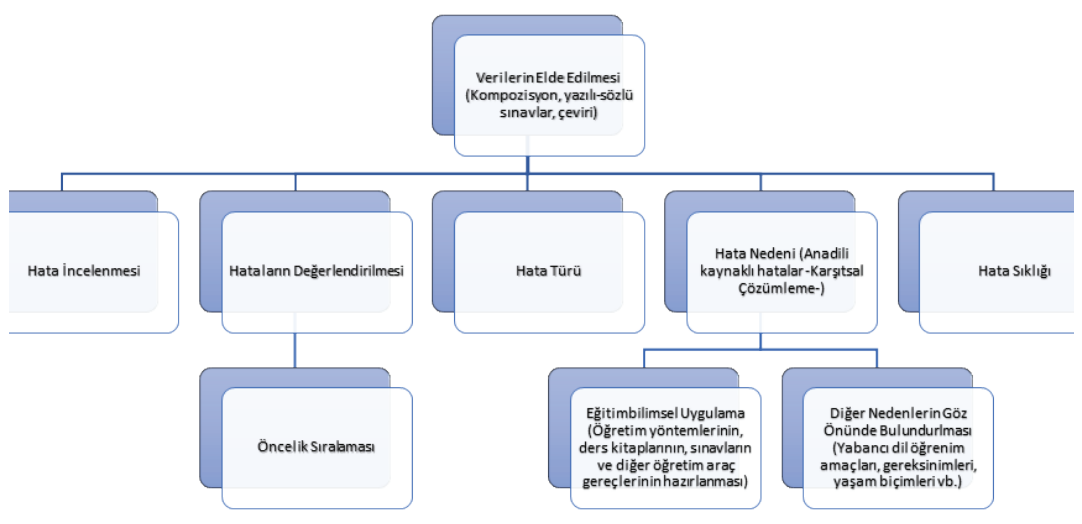

Çalışmamızda, Bayraktaroğlu'nun sunduğu bu hata çözümleme aşamaları dikkate alınarak çalışma gurubundan elde edilen veriler analiz edilmiştir.

\subsection{Sözlüksel-Anlamsal Hataların Tanımlanması}

Yabancı dil öğrenicilerinin, öğrenim süreçlerinin belirli aşamalarında öğrenme sorunları yaşadıkları ve bu sorunların öğrenim süreci boyunca değişkenlik gösteren yapılarla, hata olarak ortaya çıktığ 1 görülmektedir. Keshavarz, hata çözümlemesinde her ne kadar anadili aktarımı hata kaynağı olarak gösterilse de hataların oluş sebebinin sadece anadili aktarımı olmadığına inanırken, temel yardımcı etken olan hata kaynaklarının belirlenmesinin önemine vurgu yapmaktadır. ${ }^{14}$ Richards öğrenici kaynaklı hataları: Oluş ya da kaynak sebebi öğrenilen hedef dil/yabancı dil olan hatalar Diliçi ya da Gelişimsel Hatalar ${ }^{15}$ ve oluş ya da kaynak sebebi anadili olan Dillerarası Aktarım Hataları ${ }^{16}$ şeklinde, iki temel neden üzerine sınıflandırmaktadır. ${ }^{17}$

Keshavarz ise dilsel özellikleri açısından bu hataları üç ana başlık altında sınıflandırmaktadır:

1. Yazımsal Hatalar

a. Yazıbirim Hataları

b. Yazma Hataları

2. Sözlüksel-Anlamsal Hatalar

a. Diliçi/Gelişimsel Hataları

b. Dillerarası Aktarım Hataları

3. Dilbilgisel Hatalar ${ }^{18}$

14 Mohammed Hossein Keshavarz, Contrastive Analysis and Error Analysis, Tehran: Rahnama Puclications, 2012, s.118-119.

15 Intralingual Errors -خطاهاى ميانزبانى يا بيشرفتى

16 Interlingual Errors- خطاهاى درونزبانى ينانى

17 Jack C. Richards, A Non-Contrastive Approach to Error Analysis, San Fransisco: Tesol Convention, 1970, s.3; Ömer Demircan, Yabancı Dil Öğretim Yöntemleri, İstanbul: Ekin Eğitim Yayınc1lık, 1990, s.61.

18 Mohammed Hossein Keshavarz, Contrastive Analysis and Error Analysis, s.75. 
Çalışmanın ana evrenini oluşturan Sözlüksel-Anlamsal Hatalar grubunu yabancı dil olarak Farsça öğretimi alan araştırmacılarından Gilledârî sözcük üretimi ${ }^{19}$ hataları olarak adlandırmış ve bu gruptaki sözcük üretim hataları için şu açıklamayı yapmıştır: "Sözcük üretimi hatalarl, ögrenicinin bir kavramı aktarmak istediği ve aktarmak istediği kavramı bilmediği durumlarda, bildiği sözcükler ve sözcük üretim kuralları ile okuyucuya aktarmak istediği kavramı iletmek için ortaya koyduğu üretme çabadır." 20

Öğreniciler, yabancı dil yolu ile iletişim kurarken sözcük kullanımlarında hatalı üretimler yapmaktadırlar. Sözlüksel-anlamsal hatalar, sözcük, anlamı ve öğrenilen hedef dildeki kullanımı hakkında hedef dil öğrenicisinin yetersiz bilgisinden kaynaklanmaktadır. Keshavarz, sözlükselanlamsal hataları, yabancı dil öğrenicilerin anadillerinde var olan sözcükleri birebir olarak hedef dilde kullanmaları olarak açıklamaktadır. ${ }^{21}$ Literatür incelemesinde herhangi bir yabancı dili öğrenen öğreniciler arasında bu hata grubunun yazımsal hatalardan sonra en yüksek hata oranına sahip olduğu görülmektedir. Bu hata grubunda yapılan hataların yapılış sebebi, henüz hedef dili öğrenen öğrenicilerin hedef dildeki bazı sözcüklerin anlamı ve kullanışlarını bilmemesi ve anadillerinde sözcük üretiminde kullanılan kuralları hedef dile aktarma eğilimi göstermeleri olarak açıklanabilmektedir. Diğer bir ifade ile öğreniciler, anadillerinde var olan sözcüklerin özellikleri ve o sözcüklerin sahip oldukları anlamları yabancı dil öğrenirken aktarmamaları gerektiğini bilememektedirler. Bu tür hataların ortaya çıkış sebeplerinden bir diğeri, yabancı dil öğrenen öğrenicilerin anadilinde bulunmayan ve öğrenicinin de bilmediği, hedef dilde yer alan kültürel ögelerdir.

Araştırmada, Sözlüksel-Anlamsal Hatalar ‘diliçi ve dillerarası aktarım hataları' olmak üzere iki hata alt başlı̆̆ında incelenmiştir. Bu hata türünde dillerarası aktarım hataları, anadilinde bulunan bir sözcügün doğrudan alınarak hedef dilde kullanılması ya da türetimsel bir biçimde sözcük üretimi yapması biçiminde tek alt başlık altında incelenirken, diliçi ya da gelişimsel hatalar kendi ana başlığı altında değerlendirmiştir. Araştırmada, sözlüksel-anlamsal hatalar, Keshavarz'in bu hata grubu için sunduğu sınıflandırma doğrultusunda aşağıdaki tablo uyarınca çözümlenmiştir: ${ }^{22}$

19 word formation/ وازرّسازى

20 Mohammad Gilledârî, "Tahlîl-i Hatâhâ-yi Niviştârî-yi Zebânâmûzân-i Gayr-i İrânî”. Mecmûa-i Makâlât-i Semînâr-i Amûzeş-i Zebân-i Fârsî be Gayr-i Fârsizebânân, Tahran: Kânûn-i Zebân-i Fârsî, 1387hş./2008, s.350.

21 Mohammed Hossein Keshavarz, Contrastive Analysis and Error Analysis, s.102.

22 Mohammed Hossein Keshavarz, Contrastive Analysis and Error Analysis, s.102. 
Tablo 2. Sözlüksel-Anlamsal Hatalar Grubu Sınıflandırma Tablosu

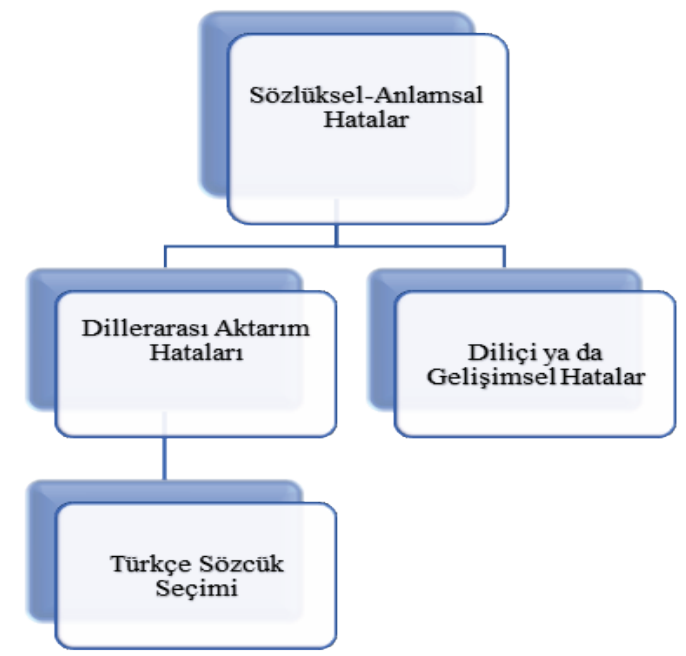

\section{Bulgular ve Yorumlar}

Çalışma soruları çerçevesinde çalışma grubumuzda yer alan yabancı dil olarak Farsça öğrenen Türk öğrenicilerin 2017-2018 Eğitim-Öğretim yılının güz ve bahar dönemlerinde 14+14 haftalık bir süreçte okudukları belirtilen derslerinin ara sınav ve yarıyıl sonu sınavları ve öğreticiler tarafından ders dönemlerinde öğrenicilere verilen ödevlerden elde edilen verilerin çözümlenmesi sonucu ortaya çıkan bulgulara ve yorumlarına yer verilmiştir. Bu doğrultuda Türk öğrenicilerden elde edilen veriler grup tablolar halinde hatalı örnek çözümleme formlarında iki temel başlık altında (A-(ب) ve (ب) satırlarında çözümlenmiştir. Çözümleme formunda yer alan (A- (الف satırında, öğreniciler tarafından üretilmiş olan hatalı cümlelere yer verilmiş ve üretilmiş olan bu hatalar ait olduğu hata grubunu belirtmek adına kırmızı renk ile vurgulanmıştır. Aynı satırda öğreniciler tarafından üretilmiş ancak farklı hata grubunda yer alan hatalı sözcük ya da yapılar altları çizilerek belirtik hale getirilmiştir. Formda öğreniciler tarafından üretilmiş ve (A- (الف) satırında yer alan hatalı cümlelerin doğru biçimleri (B-ب) satırında verilirken, hataların doğru biçimleri mavi renk ve (*) imi ile açık hale getirilmiştir.

\subsection{Sözlüksel-Anlamsal Hatalar}

\subsubsection{Dillerarası Aktarım Hataları}

Dillerarası aktarım hataları, anadilinden hedef dile yapılan olumsuz aktarımlardan kaynaklı hata türleri olarak tanımlanmaktadır. ${ }^{23}$ Yabancı dil öğretiminde hata dizgilerinin ortaya çıkmasının en temel nedenlerinden birinin anadili girişimi sayıldığını dile getirmek

23 Robert Lado, Language Teaching: A Scientific Approach, McGraw-Hill, 1964, s. 2; Seid Mohammad Ziahosseiny, Contrastive Linguistics, Tehran: Islamic University Press, 1994, s.116. 
mümkündür. Öğrenicilerin anadillerinde sahip oldukları alışkanlıkları; anadillerine ait kurallar, dil dizgesi ve sistemi gibi değişkenler hedef dil öğrenimi sırasında öğrenicileri etkilemekte ve dil çiftlerine özgü kuralları birbirlerine karıştırmalarına neden olmaktadır. Örneğin, Türkiye’de Farsça öğrenen Türk öğreniciler, işitsel ve görsel girdiler bakımından, Farsçayı İran’da öğrenen Türk öğrenicilere göre daha fazla anadili aktarımında bulunacaktır. Mîrdehkân yabancı dil öğrenicisinin, anadilinin konuşulduğu yerlerdeki hedef dil öğrenim güçlüğünü vurgulama adına şunları dile getirmektir: "Yabancı dili kendi ülkelerinde öğrenen öğreniciler, kendi sosyal ve kişisel ihtiyaçlarını karşılamak için her zaman anadillerini kullanacak ve aynı şekilde kendi anadilinde düşünmeye, dinlemeye ve konuşmaya devam edecektir. Yabancı dili ögrrenmeye çalışan ögrenicinin zihni anadilinde var olan yapı ve kullanımlar ile dolu olacak ve ögrenemeye çalıştı̆̆ yabancı dil öğrenici için ders saati sonunda sona eren, ders saati dışında neredeyse o dili hiç kullanamayacă̆ bir sınıf içi etkinlik olarak kalacaktır." ${ }^{24}$ Bütün bu etkenler dikkate alındığında yabancı dil öğreniminde anadili girişimi ve anadilinden yapılan olumsuz aktarım hatalarının etkisi kaçınılmaz bir biçimde gözlemlenmektedir. Sözlüksel-Anlamsal hata türünde hedef dil Farsça öğrenilirken öğrenicilerin anadilleri olan Türkçeden yaptıkları olumsuz aktarımlar birkaç neden ile açıklanabilmektedir. Şöyle ki Farsça öğrenen Türk öğreniciler yazılı anlatımlarında Farsça sözcükleri kullanırken sürekli olarak sözcüğün anlamını ve Türkçedeki karşılığını düşünmektedirler. Tam da bu nedenle öğreniciler tarafından kullanılan bu sözcükler tamamıyla Farsçanın bağlamına uymamakta ve hata dizgeleri olarak karşımıza çıkmaktadır. Dillerarası aktarım hataları bölümünde Farsça öğrenen Türk öğrenicilerin sözlüksel-anlamsal hataları: 'Türkçe Sözcük Seçimi’ başlığı altında incelenmiştir.

\subsubsection{Türkçe Sözcük Seçimi}

Türkçe sözcük seçimi grubunda yer alan hatalar, yabancı dil olarak Farsça öğrenen Türk öğrenicilerin Farsçanın sözlükçesinde yer alan ve yazılı anlatımlarında ihtiyaç duydukları özel sözcükleri bilmemeleri, o sözcükler yerine anadilleri Türkçede var olan ya da Türkçe ile Farsça arasında ortak olan sözcükleri ihtiyaç duydukları sözcükler yerine kullanmaları ve böylece olumsuz bir aktarımda bulunmaları sebebi ile ortaya çıkmaktadır. Aşağıdaki grup tabloda Türk öğreniciler yazılı anlatımlarında hedef dilde var olan sözcükler yerine Türkçe sözcükler kullanmış ve sözlüksel hatalar gerçekleştirmişlerdir. Öğreniciler tarafından böyle bir seçme hatasının yapılma nedeni Farsçanın sözlükçesine gerekli ve yeterli derecede hâkim olamamalarından kaynaklanmaktadır. Elbette bu sözcük seçimlerinin birçoğu, anadili ve hedef dilde bulunan ortak sözcüklerin yazım ve telaffuz farklılıklarından kaynaklanmaktadır. Aşağıdaki tabloda; sözlüksel-anlamsal hata türünde, Türkçe sözcük seçimi hata örnekleri ve bu örneklerin çözümlemelerine yer verilmiştir.

24 Mehînnâz Mîrdehkân, Âmûzeş-i Zebân-i Fârsî be Ûrdû Zebânân ve Zebân-i Ûrdî be Fârsîzebânân. Tahran: İntişârât-i Beynelmilelî-yi El-Hadî, 1380hş./2001, s.24. 
Birinci Grup Tablo: Sözlüksel-Anlamsal Hata Çözümleme Formları: Türkçe Sözcük Seçimi Hataları Örnekleri

\begin{tabular}{|c|c|c|}
\hline ب ب & & الف \\
\hline من بنج" برادر دارم. & من بش برادر دارم. & 1 \\
\hline از ميوهها انار" و موز در شهرم زياد است. & از ميوه ها نار و موز در شهرم زياد است. & 2 \\
\hline لدرختها ير از برى" و شكوفه شدند. & درخت ها با يايراكى و شوكوفه ير از شدند. & 3 \\
\hline زبان فارسى براى من سخت" نيست. & زبان فارسى براى من زور نيست. & 4 \\
\hline تيم ملى تركيه قهرمان" شد. . & نيم ميلى تركيه شامييون شد. & 5 \\
\hline ز زينب" دختى بادب است. & زينتِ دختز بَادب است. & 6 \\
\hline دوستم احمد " خيلى درسخوان است. & آمت دوست من خيلى درسخواند است. & 7 \\
\hline از خستكى نتوانستم به سر كلاس " بيايم. & از خستهكى نتوانستم به درس بيايم. & 8 \\
\hline خواهر " من در استانبول درس مى خواند. & من باجيم استانبول درس مى خواند. & 9 \\
\hline او با ماشين" به دانشكاه آمد. & او با آربا به دانشكاه آمد. & 10 \\
\hline اين تابستان من دييلمم "راكرفتم. & اين تابستان من دييلومام راكرفتم. & 11 \\
\hline او شمارة" تلفن دوستم را خواست. & او نومارا تلفن دوستم را خواست. & 12 \\
\hline من زبان* فارسى را ياد مى گيرم. & من ديل فارس ياد مى كنم. & 13 \\
\hline در دبيرستان من بسكتبال" بازى كرده بودم. & در دييرستان من باسكتبول بازى كرده بودم. & 14 \\
\hline بإيتخت فرانسه" بپاريس است. & بإِيتخت فرانسا بِاريس است. & 15 \\
\hline من هفتذ كذشتهن" در استانبول نبودم. & من دون هفتا در ايستانبول نبدم. & 16 \\
\hline آنكارا شهر بزرگى است و در عين حال * بايتخت تركيه است. & انكارا شهر بزرگى است و همان زامان بايتخت تركيه است. & 17 \\
\hline امروز ما كالاس نداريم. & امروز ما درس نداريم. & 18 \\
\hline كوههاى" تركيه بلند هستند. & داغهاى تركيه بلند هستند. & 19 \\
\hline در آن كيف "كتاب، دفتر و قلم" نيست. & آن جانتا در كتاب، دفتز و كالم ندارد. & 20 \\
\hline خواهر امين سيب و توت" را دوست ندارد. & خواهرت امين سيب و دوت را دوست ندارد. & 21 \\
\hline بعد از كلاس به خوابكاه" بركثتم. & بعد از كلاس به يورد برگشتم. & 22 \\
\hline من از شير* آب نوشيدم. & من از حشمه آب نوشيدم. & 23 \\
\hline در مسير" موفقيت اين برايم مهم بود. & در يول موفقيت اين برايم مهم بود. & 24 \\
\hline بعد از اتوبوس ما يك تاكسى كرايه كرديع". & بعد از اتوبوس ما يك تاكسى كيرالديم. & 25 \\
\hline شما جرا از آن طرف" مى رويد؟ & شما جرا از آن تاراف مى روي؟؟ & 26 \\
\hline على آدم* خوبى است. & على آدام خوبي است. & 27 \\
\hline ماشين قرمز" رنخ گران است. & ماشين قيرمزى رنك گران است. & 28 \\
\hline اين فيلم خيلى عجيب" بود. & اين فيلم خيلى اجايلٍ بود. & 29 \\
\hline
\end{tabular}

Yabancı dil olarak Farsça öğrenen Türk öğrenicilerin, birinci grup tabloda Türkçe sözcük seçimi ile yapmış oldukları dillerarası aktarım hataları örnek çözümlemelerinden, Türk öğrenicilerin Farsçanın sözlükçesinde yer alan ve yazılı anlatımlarında ihtiyaç duydukları doğru ve uygun sözcükleri, ifade kalıplarını bilmemeleri nedeniyle, anadilleri Türkçede bu Farsça sözcük ve ifade kalıpların karşılığı olan Türkçe sözcük ve ifade kalıplarını kullanmış oldukları saptanmıştır. Türkçe sözcük seçimi hata grubunda çözümlemeleri yapılan örneklerde öğrenicilerin; Ö.1/ بش

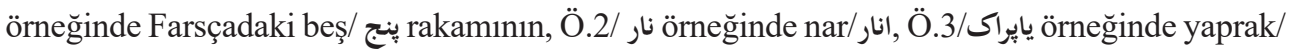

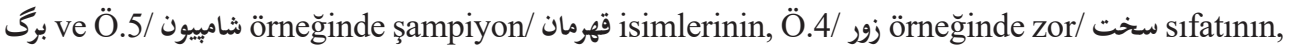

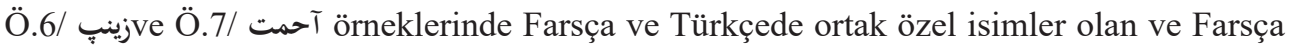
yazılışlarında yazıbirim değişimleri olan Zeynep/ زينب ve Ahmet/ احمد isimlerinin, Ö.8/ دوس ve vagh ve Ö.18/ örneklerinde Türkçeden farklı olarak anlamsal bir eşdizim değişkenine sahip olan

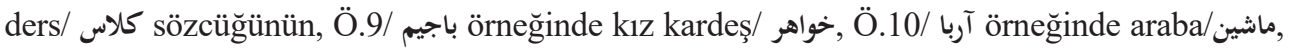




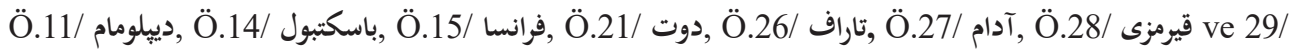

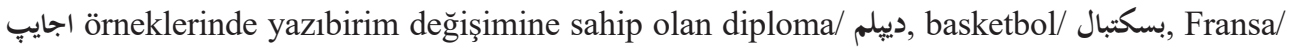

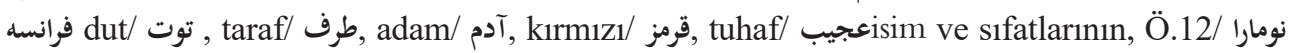

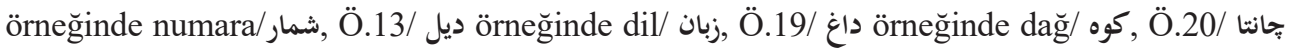

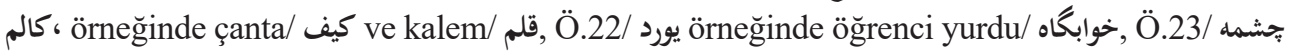

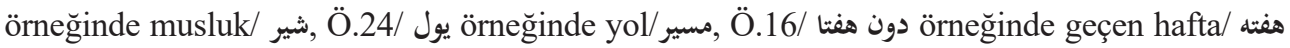

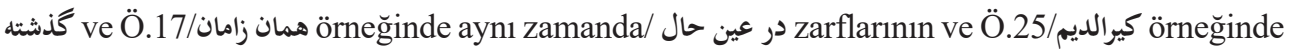
kiralamak/كرايه كردن fiilinin Farsçadaki kullanımlarını bilmemeleri sonucunda anadilleri Türkçeden olumsuz aktarımda bulundukları anlaşılmıştır. Öğreniciler, anadilleri Türkçe ile düşünmüş ve ihtiyaç duydukları Farsça sözcük ve ifade kalıpları için Fars alfabesinde yer alan yazıbirimler ile anlamsız sözcükler üretmişlerdir.

\subsubsection{Diliçi ya da Gelişimsel Hatalar}

Diliçi ya da gelişimsel hatalar, öğrenicilerin dil çiftlerine ait benzerlik ve farklılıkları birbirlerinden ayırmadaki yetersizliklerinden daha çok yabancı dil öğrenim sürecinin belirli aşamasında yapmış oldukları genellemeler sonucu ortaya çıkan gelişimsel hatalarını yansıtmakta ve öğrenicilerin dil edinimlerine dair genel özellikleri örneklendirmektedir. ${ }^{25}$ Richards, öğreniciler tarafından anadili ve hedef dilde olmayan yeni kuralların geliştirildiği diliçi ve gelişimsel hataları dört başlık halinde açıklamaktadır:

1. Aşırı Genelleme: Yabancı dil öğrenen birey, hedef dilde öğrendiği bir yapıdan yola çıkarak dilin diğer kurallarını bulmaya çalışır. Böyle olduğunda, öğrenici hedef dildeki bazı yapıları aşırı genelleyerek bozuk yapılar oluşturur. Bu durum genellikle öğrenicinin öğrenme yükünü azaltma ve dilde fazla olarak gördüğü yapıları eksiltme eğiliminden kaynaklanır.

2. Kural Kısıtlamalarını Bilmeme: Bu hata türü, aşırı genellemeye çok fazla benzemektedir. Öğrenicilerin kurallardaki özel kısıtlamaları ayırt edememeleri hata yapmalarına neden olmaktadır. Bir kuralın, uygulanmaması gereken yapılara uygulanması sonucu yapılan bu hatalar, yabancı dil öğrenimi sırasında en çok yapılan hata türlerindendir.

3. Kuralların Eksik Uygulanması: Bu tür hatalar, öğrenicinin anlamlı bir yapı oluşturmak için bilmesi gereken kuralları, tam olarak öğrenip uygulayamamasından kaynaklanmaktadır.

4. Yanlış Kavram Geliştirme: Bu tür hatalar, yabancı dil öğrenirken bir yapının yanlış anlaşılmasından dolayı oluşturulan bozuk yapıları kapsamaktadır. Bu yapıların öğrencinin anadilinde ve hedef dilde herhangi bir karşılığı olmayabilir. ${ }^{26}$

Diliçi ya da gelişimsel hata grubunda yer alan hatalar, hata kaynakları bakımdan anadilinin hiçbir etkiye sahip olmadığı ve anadilinin en temel nedenler arasında yer almadığı hatalar olarak tanımlanmaktadır. ${ }^{27} \mathrm{Bu}$ tür hataların yabancı dil öğrenicileri tarafından üretilme nedeni

25 Jack C. Richards, A Non-Contrastive Approach to Error Analysis, s.3.

26 Jack C. Richards, A Non-Contrastive Approach to Error Analysis, s.9-21; Fatma Bölükbaş, “Arap Öğrencilerin Türkçe Yazılı Anlatım Becerilerinin Değerlendirilmesi”, Turkish Studies, 6/3, (2011), s. 1359.

27 Mohammad Gilledârî, “Tahlîl-i Hatâhâ-yi Niviştârî-yi Zebânâmûzân-i Gayr-i İrânî”, s.351. 
tamamen o yabancı dilde bulunan sözcük ya da sözcük türlerinde aranmaktadır. Öğreniciler bu hata türünde daha önceki örneklerde de bahsedildiği üzere hedef dilde uygun sözcük ya da sözcük türlerini kullanmayarak, aynı anlama fakat farklı kullanım özelliklerine sahip hedef dilin kullanım alanında olan sözcük ya da sözcük türlerinin kullanımlarında seçme hataları yapmaktadırlar. Öğrenicilerin, çağrışımsal olarak doğru kabul ettikleri bu dil tutumları hedef dil özelinde o dile ait diliçi ya da gelişimsel hata dizgeleri oluşturmaktadır. Öğreniciler tarafından üretilen bu diliçi ya da gelişimsel hata dizgelerinin en temel nedeni, öğrenicilerin o dile ait sözcüklerin kullanımına dair yeterli dilsel edinimi gerçekleştirememeleri, doğru sözcük yerine o dilde bulunan hatalı bir sözcüğü seçmeleri ve bunun sonucu sözlüksel-anlamsal hatalar oluşturmalarıdır. Aşağıdaki tabloda; sözlüksel-anlamsal hata türünde, diliçi ya da gelişimsel hatalı sözcük üretim örnekleri ve bu örneklerin çözümlemelerine yer verilmiştir.

İkinci Grup Tablo: Sözlüksel-Anlamsal Hata Çözümleme Formları: Diliçi ya da Gelişimsel Hatalı Sözcük Üretim Örnekleri

\begin{tabular}{|c|c|c|}
\hline ب & & لف \\
\hline من براى خواندن كتاب وقت * نداشتم. & من براى خواندم كتاب رمان نداشتم. & 1 \\
\hline |امتحان ادبيات ديروزى خيلى سخت * بود. & ديروز امتاهان ادبيات خيلى مشكيل بود. & 2 \\
\hline البته درباره اين موضوع ديدگًاههاى" خختلف هست. & البته درباره اين موضوع فكرهاى ححطلف هست. & 3 \\
\hline ياد كرفتن فارسى براى من سخت" نيست. & ياد گرفن فارسى براى من مسكل نيست. & 4 \\
\hline تقريباً نصف * كتاب را خواندم. & تاكريبى نيم كتاب را خواندم. & 5 \\
\hline ما مسلمانان نماز مى خوانيم". . & ما مسلومانان ناماز مى كنيم. & 6 \\
\hline اين تعطيل براى استراحت كردن فرصت خوبى بود. & اين تعاتيل براى استرحت كردن فرصت نيك بود. & 7 \\
\hline اميدوارم* يك سال بعد متزجم بشوم. & اميد دارم يك سال يِ مترجم بشم. & 8 \\
\hline دستم را در* جيبم كردم. & دستم را به جيبم كردم. & 9 \\
\hline آسمان امروز ابرى نيست". & السمان امروز ابر ندارد. & 10 \\
\hline سفيد و آبى رنگهاى آرامبخش * هستند. & سفيد و ابى رنگهاى ارام هستند. & 11 \\
\hline امروز هوا آفتابى* است. & امروز هوا افتاب است. & 12 \\
\hline 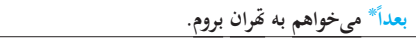 & بـ مي ميخواهم به تاهران برم. & 13 \\
\hline او معمولاً فيلمهاى كمدى * تماشا مى كند. & او مامولن فيلم هاى كميك تماشا مى كند. & 14 \\
\hline افراد* ديكر هم براى آن ترم آمده بودند. & نفرهاى ديكر هم براى آن ترم آمده بودند. & 15 \\
\hline آن روز كتابخانه خيلى خلوت * بود. & آن روز كتابخانه خيلى خالى بود. & 16 \\
\hline بعد من موضوع را فهميدم". & بعد من موضوع را دانستم. & 17 \\
\hline در طول " آن مسافرت با ايرانىها صحبت كردم. & در مدت آن مسافرت با ايرانىها صحبت كردم. & 18 \\
\hline وقتى كه يدر و مادرم را مى بينم، خوشحال مى شوم". & وقتى كه يدر و مادرم را ديدم، خوشوقت شدم. & 19 \\
\hline فوتباليستهاى" تركيه در دنيا شهرت بزرگى ندارند. & فوتبل بازيها تركيه در دنيا شوحرت بزرگ ندارند. & 20 \\
\hline من يياده" به دانشكاه مى روم. & 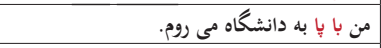 & 21 \\
\hline اصفهان شهر قديمى بود. & اسفهان شهر بير بود. & 22 \\
\hline من فارسى ياد مي گيرم". & من تعلم فارسى مى كنم. & 23 \\
\hline آن روز خيلى خوش * كذشت. & آن روز خيلى خوب گذشت. & 24 \\
\hline در تركيه دانشگاههاى زيادى وجود دارد. & در تركيه بيشتز دانشگاهها وجود دارد. & 25 \\
\hline او دير وارد كلاس شد". & | او دير به كلاس ورود كرد. & 26 \\
\hline من هم كيتار مى زنخ". & من هم گيتار بازى مى كنم. . & 27 \\
\hline ما در تركيه اين روز را جشن مى گيريم". & ما در تركيه اين روز را هشن مى كنيم. & 28 \\
\hline او به من كمك مى كند". & او به من كمك مى دهد. . & 29 \\
\hline ساعت هشت سوار هواييما شدم". & ساعت هشت به هواييما سوار كردم. & 30 \\
\hline
\end{tabular}




\begin{tabular}{|c|c|c|}
\hline تماشا كردن اين بجههاى بيجاره مرا خيلى غمكين مى كند". & تماشاكردن اين بجههاى ناجار مرا زياد غمكين مى شود. & 31 \\
\hline يسرم در جاهاى شلوغ از بيش من دور مى شود". & بسرم در جاهاى يرجمعيتترين از ييش من دور مى كند. & 32 \\
\hline آن داستان تأثير * بزركى بر من گذاشت". & آن داستان تاسير بزرگى به من كرد. & 33 \\
\hline من با او صحبت كردم". & 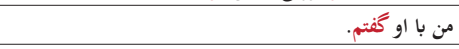 & 34 \\
\hline | اين رشته را خودم انتخاب كردم". & اين رشته را خودام ترجيح كردم. & 35 \\
\hline در اين دانشگاه زبان فارسى مى خوانز". & در اين دانشگُاه زبانى فارسى درس مى خواني. & 36 \\
\hline من اين زبان را خيلى دوست دارم اما نمى توانم موفق شوم". & من اين زبان را خيلى دوست دارم اما نمى توانم موافق كنم. & 37 \\
\hline او جواب مرا قبول نى كند". & او جواب من راكابول نى شود. . & 38 \\
\hline |حتمال دارد" ما دير بيدار بشويم. & ما احتمال داريم دير بيدار بشويم. & 39 \\
\hline يك مركز زبان فارسى يبدا"كردم و دوست داشتم (آنجا) ثبت ن نام كنم. & يك مركز زبان فارسى يياده كردم و دوست داشتم سنت كنم. & 40 \\
\hline من مى خواهم * سال آينده به ايران بروم. & من خواهش دارم كه سال آينده به ايران بروم. & 41 \\
\hline | استادم به من زبان فارسى ياد مى دهد.". & استادم به من زبان فارسى ياد مى گير. الـ & 42 \\
\hline |و را به بيمارستان ببر". & او را به بيمارستان برو. & 43 \\
\hline | اين كار مرا ناراحت كرد". & 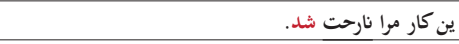 & 44 \\
\hline | دوستم در را زد". & دوستم در را زنگ زد. & 45 \\
\hline من از استاد حيز زيادى ياد گرفتم*. & من از استاد زياد هيز ياد دادم. & 46 \\
\hline | در اين جهان دشوارىهاى بى شمارى هست". & در اين جهان دشوارها بى شمار دارند. & 47 \\
\hline در دانشكدهام گربه هست". & در دانشكدة من گربه دارد. & 48 \\
\hline در كلاس ما بيست نفر هست". & در كلاس ما بيست شخصى داريم. & 49 \\
\hline 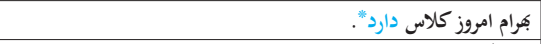 & 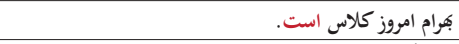 & 50 \\
\hline دانشكاهمان در مركز آنكارا است*. & دانشكاهمان در بين آنكارا هست. & 51 \\
\hline لطفاً زود به آمبولانس زنگ بزنيد. ل & لطفاً همان آمبولانس را جستجو كند. & 52 \\
\hline آكر (در زبان فارسى) بيشرفت كنم، به ايران خواهم رفت. & وقتى من كافى مى شوم، به ايران مى روم. & 53 \\
\hline بايد انسانها مهربان باشند". & بايد انسانها مهرابان بشوند. ب ل & 54 \\
\hline | همه بدرها شجاع و قدرتمند هستند". & همه بدرها شوجا و كودرت دارند. & 55 \\
\hline اسم آن شيء را از" دوستم يرسيدم. & اسم آن شى را به دوستم يرسيدم. & 56 \\
\hline
\end{tabular}

İkinci grup tablolar diliçi ya da gelişimsel hatalı sözcük üretimi sözlüksel-anlamsal hatalarda, çözümlemeleri yapılan örneklerden yabancı dil olarak Farsça öğrenen Türk öğrenicilerin bu hata türünde dil öğrenim süreçlerinde edinimini gerçekleştirmiş oldukları Farsça sözcük ya da sözcük türlerini bir diğerinin yerine kullanma eğilimi gösterdikleri ve hedef dil Farsçanın etkisi ile çeşitli seçme hataları yaptıkları saptanmıştır. Daha önce de belirtildiği üzere öğrenicilerin böyle bir gelişimsel hata yapmalarının nedeni tamamen öğrenimini gerçekleştirdikleri yabancı dil kaynaklarında aranmalıdır. Öğrenicilerin üretmiş oldukları bu hatalı kullanımlar, henüz eşanlam ya da eşdizime (birlikte kullanım) ${ }^{28}$ sahip olan sözcük ya da sözcük türlerinde gerekli dilsel girdiyi sağlayamadıklarını da göstermektedir.

Sözlüksel-anlamsal hata türünde çözümlemeleri yapılan örnekler, bu hataların öğrenicilerin iletişim stratejilerinden kaynaklı olduğunu belirtmektedir. Diğer bir ifadeyle öğrenicilerin, hedef dilde kullanmak istedikleri doğru sözcük ya da sözcük türlerini bilmedikleri durumlarda sözcügün zıt ya da eşanlamlısını, ona en yakın olan sözcük ya da sözcük türlerini kullanma eğilimi gösterdikleri belirlenmiştir. Bu hata türünde çözümlemeleri yapılmış olan örneklerde öğrenicilerin; Ö.1 örneğinde vakit/ وقان yerine, Ö.2 örneğinde zor/ سخت yerine مشكيل, Ö.3

28 collocation/باهم آيى، هم آيش 


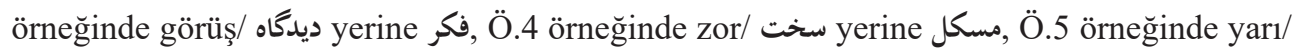

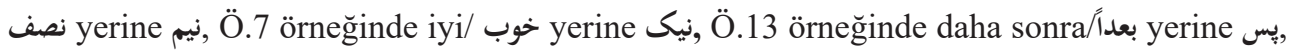

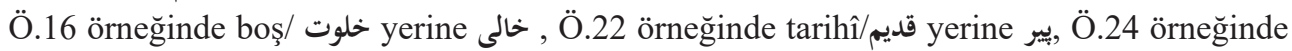

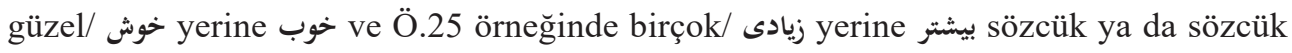
türlerini kullanarak sözlüksel-anlamsal diliçi aktarım hataları yapmış oldukları saptanmıştır. Öğreniciler, hedef dil Farsçada var olan ve yukarıda hatalı kullanımları belirtilen örneklerde doğru kullanımları verilen ve hedef dil Farsçada farklı anlamsal bağlamlara sahip olan sözcükler için zıt çağrışımda bulunarak hatalı sözcük seçimi yapmış oldukları belirlenmiştir. Öğrenicilerin bu sözcük ya da sözcük türleri için hatalı bir şekilde zıt çağrışımda bulunmalarının nedeni, kendi anadillerinde var olan ve tek sözcük ile karşılanan kavramlar için Farsçada birden fazla kavramın bulunması olmuştur.

Bu hata grubunda yer alan diğer örneklerde öğrenicilerin, hedef dil Farsçada kısıtlı olan bilgileri ile kendilerini yazılı anlatımlarında ifade edebilmek için iletişim stratejileri kaynaklı olarak diliçi hatalar yapmış oldukları görülmüştür. Bu grupta yer alan iletişim stratejileri kaynaklı hatalarda öğrenicilerin; Ö.8 örneğinde umarım/اميدوارم/ Yerine Ö. 11 örneğinde

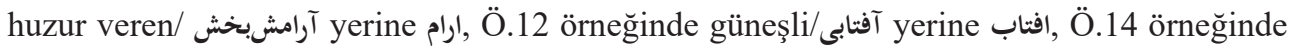

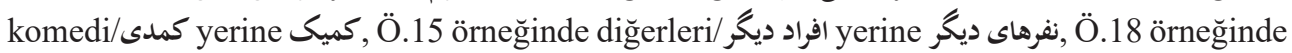

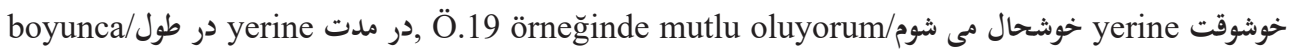

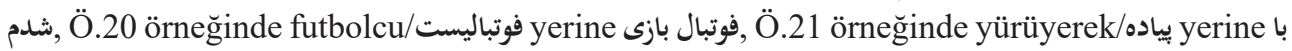

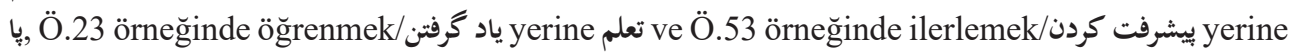
sözcük ya da sözcük türlerini kullanarak sözlüksel-anlamsal diliçi aktarım hataları yapmış oldukları saptanmıştır.

Eşdizimlilik/Birliktelik iki ya da daha fazla dil biriminin belirli sınırlılık içerisinde düzenli bir biçimde birlikte kullanılmaları durumu biçiminde tanımlanmaktadır. ${ }^{29}$ Eşdizimliliğe dair bu grupta üretilmiş olan hata örneklerinde öğrenicilerin; Ö.6 örneğinde namaz k1lmak/نماز خواندن

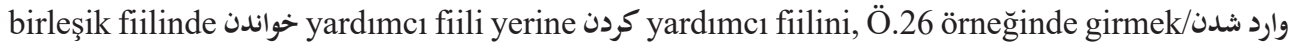

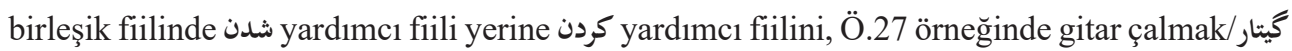

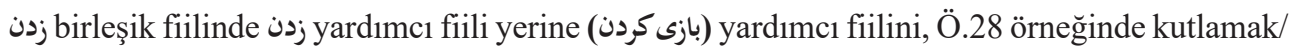

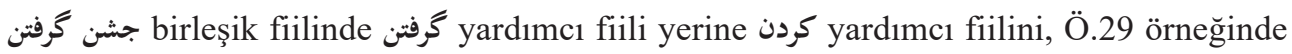

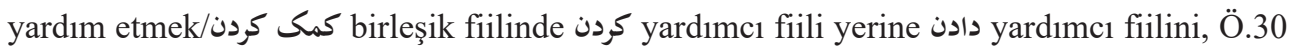

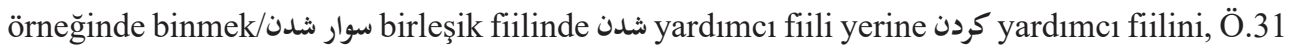

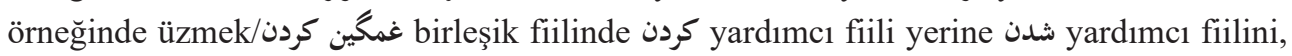

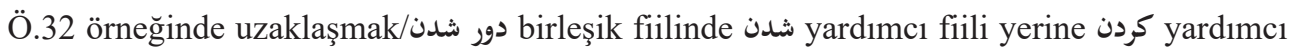

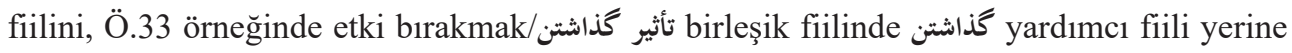
مونق شدن/yardımcı fiilini, Ö.37 örneğinde başarılı olmak مردن birleşik fiilinde شدن

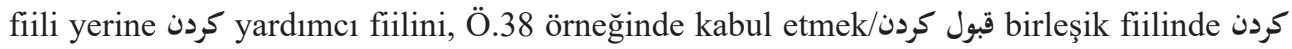
yardımc1 fiili yerine شدن yardımc1 fiilini, Ö.42 örneğinde öğretmek/ياد دادن/ birleşik fiilinde

29 Berke Vardar, Açıklamalı Dilbilim Terimleri Sözlüğü, İstanbul: Multilingual Yayınları, 2002, s.94. 
ناراحت كردن/yardımc1 fiilini, Ö.44 örneğinde rahatsı etmek گُفتن yardımc1 fiili yerine دادن

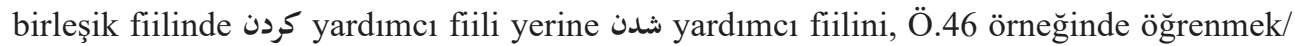

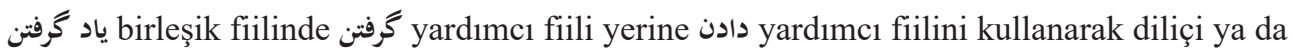
gelişimsel kullanım hataları yapmış oldukları belirlenmiştir. Öğreniciler tarafından yapılan bu eşdizim hataları, Farsçada birleşik fiillere ait birlikte kullanım gerekliliğinin yeterli düzeyde edinilmediğini göstermektedir.

Hedef dil Farsçada fiillerin doğru kullanımına dair bu grupta belirlenen diğer hatalarda öğrenicilerin; Ö.10, Ö.47, Ö.48, Ö.49 ve Ö.55 örneklerinde var olmak/bulunmak anlamındaki هستن fiili yerine sahip olmak anlamındaki داشتن fiilini kullandıkları, Ö.450 örneğinde dersi olmak Farsçadaki eşdizimi ile derse sahip olmak/ كلاس داشتن birleşik fiilinde داشتن yardımc1 fiili yerine است ek fiilini, Ö.451 örneğinde است ek fiilinin yerine doğrudan var olmak/bulunmak anlamındaki هستن fiilini kullandıkları, Ö.54 örneğinde eş anlamlılığa sahip olan fakat farklı bağlam ve işlev kullanılan olmak anlamındaki بودن fiilinin yerine شدن fiilini kullandıkları, Ö.417 ص̈rneğinde anlamak/ فهميدنfiili yerine bilmek/ دانستنfiilini, Ö.34 örneğinde sohbet etmek

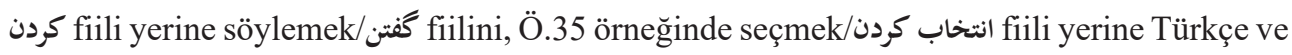
Farsçada ortak olan ancak yalancı eşdeğerliği sebebiyle Farsçada farklı bağlamsal kullanıma sahip olan ترجيح كردن fiilini, Ö.36 örneğinde eğitim görmek/okumak anlamında kullanılan خواستن/fiilini, Ö.41 örneğinde istemek درس خواندن fiili yerine ders çalışmak anlamındaki خواندن كردن

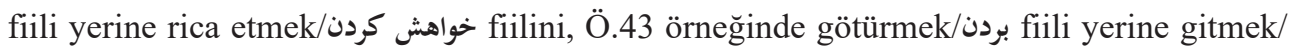

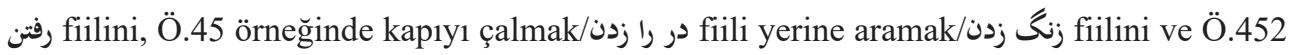
örneğinde telefon etmek/aramak anlamındaki زنخ زدرن fiili yerine -i bulmaya çalışmak/aramak anlamındaki جستجو كردن fiilini kullanarak diliçi ya da gelişimsel hatalar yaptıkları saptanmıştır.

Sözdizimsel ilişkilerinde Farsçada Türkçedekinden farklı bir eşdizime sahip olan ve sözcükler ile fiiller arasında Türkçeden farklı anlamlar kuran ad durum ekleri ve edat kullanımı kaynaklı hatalarda öğrenicilerin; Ö.33 örneğinde / بر / edatı yerine / به/ / yönelme durumu ekini, Ö.56 örneğinde / ز / ayrılma durumu eki yerine / به / yönelme durumu ekini ve Ö.9 örneğinde / / به / yönelme durumu ekini kullanarak Farsça ve Türkçede farklı eşdizime sahip bu ekler ile ilgili kural kısıtlamalarını bilmemelerinden kaynaklı diliçi ya da gelişimsel hatalar yaptıkları belirlenmiştir.

\section{Tartışma ve Sonuç}

Bu araştırmada, araştırmanın çalışma grubunda yer alan öğrenicinin Farsça yazılı anlatım hataları, 'Sözlüksel-Anlamsal Hata Grubu' başlığı altında incelenmiş ve bu hataların oranlarına ilişkin frekans ve yüzde dağılımları saptanmıştır. Bu hata grubunda elde edilen bulgular doğrultusunda ulaşılan frekans ve yüzde dağılım sonuçları şu şekildedir: 


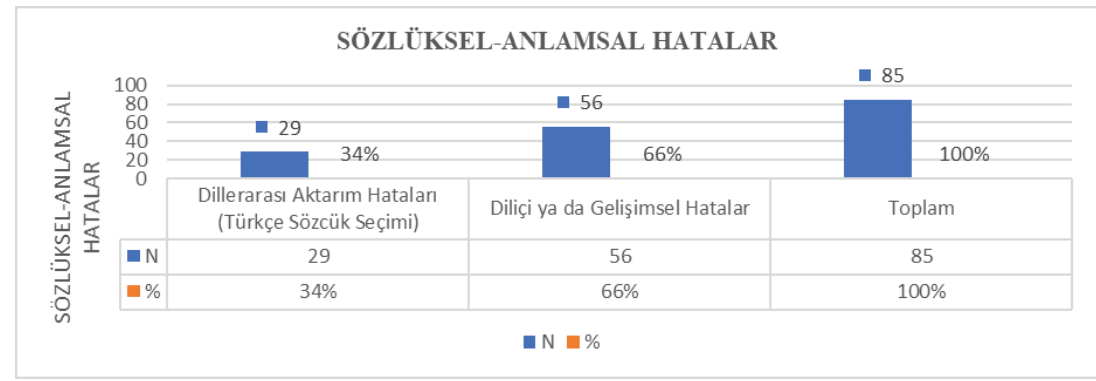

Grafik 3. Sözlüksel-Anlamsal Hata Oranlarına İlişkin Frekans ve Yüzde Dağılımları

Grafik 3 incelendiğinde, yabancı dil olarak Farsça öğrenen Türk öğrenicilerden elde edilen veriler doğrultusunda sözlüksel-anlamsal hata türünde tespit edilmiş olan toplam 85 hatanın; 56 hata frekansı ve \%66'lık oranla diliçi ya da gelişimsel hatalar, 29 hata frekansı ve \%34'lük oranla dillerarası aktarım, Türkçe sözcük seçimi hataları olduğu saptanmıştır. SözlükselAnlamsal hata türünde toplam hatanın yarısından fazlasını \%66'lık bir oranla oluşturan diliçi ya da gelişimsel hataların, dillerarası yani anadili Türkçe girişiminden kaynaklanan hata oranından fazla olması dikkat çekmektedir. Çünkü yabancı dil olarak Farsça öğretimi alanında hata çözümlemesi yapılan çalışmalarda, hedef dilin kendi ortamında öğrenilmemesi ön kabulü, araştırmacılara hedef dil ile ilgili öğrenicilerin daha fazla dillerarası aktarım hataları yapacaklarını öngörmektedir. Bu çerçevede ilgili alanda yazılı anlatım hatalarına yönelik Türkiye dışında yapılan birçok araştırma verileri hata oranlarını şu şekilde tespit etmiştir: Mîr İsmâilî (1380hş./2001) ilgili çalışmasında anadili girişimini, öğrenici hatalarındaki en önemli etken olarak belirlemiş ve Farsça öğreniminde öğreniciler tarafından yapılan diliçi aktarım hatalarını, öğrenicilerin öğrenme yollarını, dillerarası aktarım hatalarını öğrenici hatalarının ortaya çıkış nedenleri arasında göstermiştir. Araştırma sonucunda, yazılı anlatımlarında hata oranları yüksek olan öğrenicilerin, dillerarası hatalarının daha fazla olduğu tespit edilmiştir. Nevvâbî Kâmserî (1385hş./2006) tarafından yapılan çalışmada Farsça öğrenen elli Arap öğrenicinin hataları; 1. Anadilinden hedef dile yapılan dillerarası aktarım hataları. 2. Hedef dil öğrenim sürecinden kaynaklı diliçi aktarım hataları. 3. İletişim stratejileri kaynaklı hatalar. 4. Eğitsel yöntemler ve ders araç-gereçlerinden kaynaklı hatalar başlıkları altında incelenmiş ve araştırma sonucunda dillerarası aktarım hataları kaynaklı hata oranının diğer hata oranlarından daha fazla olduğu tespit edilmiştir. Gilledârî’nin (1386hş./2007) Farsça öğrenen 300 yabanc1 öğrencinin yazılı metinlerindeki hataları incelediği çalışmasının sonucu 316 hata arasında, 193 hatanın sözlüksel-anlamsal hata, 123 hatanın yapısal hata olduğunu göstermiştir. Çalışmada, Farsça öğrenenlerin en fazla yaptığı hata yığılımının sözlüksel-anlamsal hatalar olduğu ve bunların birçoğunun dilsel yapı bağlamında sözcüklerin kullanımından kaynaklanan dillerarası hatalar olduğunu tespit etmiştir. Hong’un (1389hş./2010) Vietnamlı Farsça öğrenicilerinin dilbilgisel hatalarını incelediği çalışmasının sonucu dilbilgisel hata oranları dikkate alındığında 
ilk sırada en fazla hatanın öğretim yöntemleri ve ders araç-gereçlerinden kaynaklandığı ve daha sonra ikinci sırada en fazla hatanın anadili aktarımı yani dillerarası hatalardan kaynaklı hatalar olduğunu göstermiştir. Ahmedvend (1389hş./2010) Farsça öğrenen 34 başlangıç düzeyi Alman öğrenicinin hatalarını incelediği ve hata sıklık oranlarını verdiği çalışmasında, öğrenici hatalarını yazıbirim hataları, sözlüksel-anlamsal hatalar, dilbilgisel hatalar ve yazımsal hatalar başlıkları altında sınıflandırmıştır. Araştırma sonucu, yabancı dil olarak Farsça öğrenen Alman öğrenicilerin en fazla hatayı sırası ile yazıbirim hataları, sözlüksel-anlamsal hatalar içerisinde dillerarası aktarım hataları, dilbilgisel hatalar ve yazımsal hatalarda yaptıkları tespit edilmiştir. Kûşlîpûr (1390hş./2011) ilgili çalışmasında ortaokul düzeyindeki Farsça öğrenen erkek Türkmen öğrencilerin kompozisyonlarından elde etmiş olduğu veriler doğrultusunda öğrenci hata yoğunluğunu şu şekilde tespit etmiştir: 1. Anadili aktarımı dillerarası aktarım kaynaklı dilbilgisel hatalar, 2. Hedef dil öğrenim süreci kaynaklı dilbilgisel hatalar, 3. İletişim stratejileri kaynaklı dilbilgisel hatalar, 4. En yüksek orana sahip olan öğretim yöntemleri ve ders araç-gereçleri kaynaklı hatalar. Alevî Mukaddem ve Hayrâbâdî (1391hş./2012) orta ve ileri düzey anadilleri Farsça olmayan öğrencilerin yazılı anlatım hatalarını değerlendirdikleri çalışmalarında, \%72'lik oranla yazılı anlatımlarında en fazla yapılmış olan hata türünün yapısal hatalar olduğunu, hemen ardından en fazla hata oranının \%24'lik oranla anadili girişimi kaynaklı dillerarası aktarım hataları olduğunu tespit etmişlerdir. İslâmî (1393hş./2014) çalışma grubunu oluşturan Rus öğrenciler hiçbir özellik gözetilmeksizin Moskova, Saint Petersburg ve Astrahan Üniversiteleri ve aynı şekilde İran'da Dehhodâ Enstitüsünde orta düzeyde Farsça öğrenimlerine devam eden öğrenciler arasından seçmiş olduğu çalışmasında, hata yığılımının diliçi ya da gelişimsel hatalar bağlamında eşanlamlı sözcüklerin kullanımı kaynaklı olduğunu ortaya koymuştur. Alevî Mukaddem ve Hessâs Sadıkî (1393hş./2014) Kazvîn'de bulunan İmam Humeynî Üniversitesi Farsça Öğretim Merkezi'nde ileri düzeyde öğrenim gören Arap öğrenicilerin yazma becerisinde yaptıkları hatalar analiz etmiş oldukları ilgili çalışmalarında, Farsça öğrenen Arap öğrenicilerin hata sıklık oranlarını: Yapısal hatalar \%55, sözlüksel hatalar \%20, yazımsal hatalar \%15 ve konuşma hataları \%10 olarak etmişlerdir. Mîrdehkân, Ahmedvend ve Hüseynî Kârger (1393hş./2014) başlangıç düzeyinde Farsça öğrenen 34 Alman öğrenicinin yazılı anlatım hatalarını analiz ettikleri çalışmalarında, 850 hata arasında 672 yazımsal hatanın dillerarası aktarımdan kaynaklanan hatalar olduğunu, diğer 218 hatanın da diliçi aktarım hatalarından kaynaklandığını tespit etmişleridir. Mutevellîan Nâînî ve Melikiyân (1393hş./2014) hata çözümlemesi yöntemini kullanarak Farsça öğrenen Pakistanlı öğrenicilerin dilbilgisel hatalarını analiz etmişlerdir. Araştırmanın çalışma grubunu oluşturan bu Pakistanlı Farsça öğrenicileri gelişigüzel biçimde İsfahan'daki Uluslararası Al-Mustafa Üniversitesi Farsça Öğretim Merkezi’nde Farsça öğrenen öğreniciler arasından seçilmiştir. Araştırmanın verileri, öğrenicilerin Farsça öğrenimlerindeki yedi dönemlik ara sınav ve yıl sonu sınavlarından elde edilmiştir. Verilerin analizinin ardından, başlangıç, orta ve ileri düzeyde öğreniciler tarafından yapılmış 22 tür dilbilgisel hata tespit edilmiştir. Araştırmanın sonucu dillerarası aktarım hataları 
kaynaklı anadili aktarımının \% 72' lik oranla yapılmış en fazla hata olduğu belirlenmiş̧ir. Aynı şekilde hata türleri dikkate alındığında $\% 47,1^{\prime}$ lik oranla hatalı yazıbirim seçimi ve $\% 32,9$ 'luk oranla yazıbirim azaltımı hatalarının en yüksek oranlara sahip hatalar olduğu göze çarpmıştır. Araştırmanın veri analizleri düzeylere göre hata oranlarını şu şekilde açıklamıştır: Başlangıç düzeyi $\% 41,8$, orta düzey $\% 34,8$ ve ileri düzey $\% 23,4$. Bu oranlar öğrenici düzeyi arttıkça hata oranının azaldığını ve hedef dil girdilerinin olumlu yönde arttığını göstermiştir

Araştırmamızın çalışma grubunu oluşturan ve Farsçayı yabancı dil olarak öğrenen Türk öğreniciler de hedef dil Farsçayı doğal ortamı dışında yani kendi anadillerinin konuşulduğu Türkiye'de öğrenirken, öğretim sürecinde görev alan öğreticilerin çoğunun hedef dilin doğal konuşuru olmadıkları ve anadillerinin öğreniciler ile aynı olduğu bilinmektedir. Tam da bu nedenlerden dolayı çalışma grubumuzu oluşturan öğrenicilerin de daha fazla dillerarası aktarım yani anadili aktarımı yapmaları öngörülmekteydi. Ancak sözlüksel-anlamsal hata grubunda saptanan oranlar yabancı dil olarak Farsça öğrenen Türk öğrenicilerin daha çok diliçi ya da gelişimsel hatalar yaptıklarını göstermiştir. Literatür taraması sonucu yukarıda belirtilen çalışmaların çoğunda da görüleceği üzere yabancı dil olarak Farsça öğrenen öğrenicilerin yazılı anlatımlarına dair yapılan çalışma verileri öğrenicilerin genel olarak dillerarası aktarım hataları yaptıklarını göstermiş, çalışmamızda elde edilen veri sonuçları bunun aksi olarak Türk ögrenicilerin en fazla hatayı diliçi ya da gelişimsel hata türünde yapmış olduklarını tespit etmemizi sağlamıştır.

Sözlüksel-anlamsal hatalarda Türk öğreniciler tarafindan üretilmiş olan Türkçe sözcük seçim hataları, Farsça öğrenen Türk öğrenicilerin Farsçanın sözlükçesinde yer alan ve yazılı anlatımlarında ihtiyaç duydukları sözcükleri bilmemeleri ve o sözcüklerin yerine anadilleri Türkçede var olan ihtiyaç duydukları sözcükleri kullanmaları, böylece olumsuz aktarım hataları yapmaları nedeniyle ortaya çıkmıştır. Öğrenicilerin böyle bir seçme hatası yapmaları, onların Farsçanın sözlükçesinde yer alan sözcüklere yeterli ve gerekli derecede hâkim olmadıklarını, sözcük dağarcıklarının yetersiz olduğunu göstermiştir.

Yabancı dil olarak Farsça öğrenen Türk öğrenicilerin yine sözlüksel-anlamsal hatalardaki diliçi ya da gelişimsel hatalarında dil öğrenim sürecinde edindikleri sözcük ya da sözcük öbeklerini bir diğeri yerine kullanma eğilimi gösterdikleri ve hedef dil Farsçanın etkisi ile çeşitli sözcük seçim hataları yapmış oldukları belirlenmiş̧tir. Öğrenicilerin böyle bir gelişimsel hata yapma nedenleri, tamamen öğrenimini gerçekleştirdikleri hedef dil Farsça kaynaklarında aranmalıdır. Türk öğrenicilerin üretmiş oldukları bu hatalı kullanımlar, öğrenicilerin henüz Farsçada bulunan eşdizim ya da birlikte kullanıma sahip olan sözcük ve sözcük öbeklerinde gerekli dilsel girdiyi sağlayamadıklarını göstermiştir. Bu hata türünde analizleri yapılan örnekler, öğreniciler tarafından üretilmiş olan bu hataların, öğrenicilerin iletişim stratejilerinden kaynaklandığını vurgulamaktadır. Diğer bir ifade ile öğreniciler doğru sözcük ya da sözcük öbekleri yerine sözlükçelerinde yer alan ve zihinlerinde onlara doğru gelen sözcükleri seçme eğilimi göstermişlerdir. 
Sonuç olarak yapılan bu araştırma doğrultusunda, yabancı dil olarak Farsça öğrenen öğrenicilerin yazılı anlatımlarında çeşitli güçlükler çektiklerini ve dil seviyelerine göre basit hatalar yaptıklarını dile getirmek muhtemeldir. Bu doğrultuda, sözlüksel-anlamsal hata grubunda, öğrenicilerin hedef dil Farsçaya ait sözcüklerin anlam inceliklerini ve bu sözcüklerin kullanılması gereken bağlamlarına dair yetersiz öğrenmeleri göz önünde bulundurulmasının, sözcük öğretimine dair öğretim yöntemleri gözden geçirilmesinin ve daha verimli öğretim yöntemlerinden yararlanılmasının yerinde olacağı düşünülmektedir.

Araştırma kapsamında elde edilen bulgular ve sonuçlar, yabancı dil olarak Farsça öğrenen Türk öğrenicilerin yazma becerilerine yönelik eğitimbilimsel çalışmaların yapılmasının önemi ve gerekliliğini açıkça ortaya koyarken, yabancı dil olarak Farsça öğretim sürecinin tekrar gözden geçirilmesi gerekliliğini ön plana çıkarmıştır. Bu görüş dikkate alınarak tespit edilen hataların en aza indirilebilmesi ve yabancı dil olarak Farsça öğrenen Türk öğrenicilerin sözlükselanlamsal gruptaki yazılı anlatımlarının geliştirilebilmesi için sunulan öneriler şu şekildedir:

1. Dillerarası aktarım hatalarında, yani öğrenicilerin anadilleri Türkçeden kaynaklanan hata gruplarında, öğreticilerin öğrenim sürecinin her aşamasında bu hataları öngörerek anadillerini kullanmamaları önerilmektedir. Çünkü, Farsçayı yabancı dil olarak Türkiye'de öğrenen öğreniciler, hedef dil Farsçayı doğal ortamı dışında kendi anadillerinin konuşulduğu ortamda öğrenmektedirler. Bunun yanı sıra öğretim sürecinde görev alan öğreticilerin hedef dil konuşuru olmadığı değişkeni de göz önünde bulundurulursa, öğrenicilerin dillerarası aktarım hataları yapmaları kaçınılmaz olmaktadır. Bu nedenle, öğreticilerin Farsçayı yabancı dil olarak öğretimleri sürecinde gerekli görülmedik ve ihtiyaç duyulmadıkça fazlasıyla anadillerine başvurmamaları önerilmektedir.

2. Dillerarası aktarım hatalarında, anadili ve hedef dil Farsçada bulunan ortak sözcüklerin yazımlarında öğreticilerin yazıbirim farklılıklarına dikkat çekmeleri ve öğrenicilerin eksiltme ve artırım hatalarının en aza indirilebilmesi adına özellikle sözcüklerin sahip oldukları yazımsal farklılıkları vurgulamaları önemlidir.

3. Öğrenicilerin yazılı anlatımlarındaki diliçi ya da gelişimsel hatalarından hareketle öğreticilerin; sınıf içi çalışmalara ağırlık vermeleri, öğrenicilerin sözcük seçim hatalarına dikkat ederek öğrenicilerin yapmış oldukları hataları düzeltebiliyor ise anında düzeltmeleri, öğrenicilere bu hatalar ve hataların içeriklerine dair geri bildirimler vermeleri ve böylece öğrenicilerin yapmış oldukları bu hataların tekrar edilme sıklıklarının azalması ve daha verimli yazılar yazmalarının sağlanabilmesi için cesaretlendirilmeleri gereklidir.

4. Diliçi ya da gelişimsel hatalar dikkate alındığında öğrencilerin hata yapacaklarını anladıkları sözcük ya da sözcük gruplarını kullanmaktan kaçındıkları, onların yerine daha iyi bildikleri sözcükleri kullanma eğilimi gösterdikleri gözlemlenmektedir. Bu doğrultuda önceden öngörülebilecek öğrenim güçlükleri dikkate alınarak öğreticilerin, derse başlamadan önce derse ait yeni sözcükleri öğrenciler için belirlemeleri, bu sözcükler için görseller hazırlayarak öğrenicilere etkileşimli biçimde açıklamaları, sözcüklerin Farsçadaki doğru yazılışlarını tahtaya 
yazmaları, telaffuzlarının edinimi için sözcükleri birkaç kez tekrar etmeleri ve bu sözcükler ile ilgili çeşitli etkinlikler yapmaları önemlidir.

5. Diliçi ya da gelişimsel öğrenici hatalarının önlenebilmesi adına öğreticilerin, öğrenicilerin bir sözcüğü tam anlamıyla edinmeden yani Farsçada sahip olduğu işlev ve kullanım alanını pekiştiremeden yeni sözcüklerin öğretimine geçmemeleri ve böylelikle öğrenicilerin edinimini gerçekleştirmeye çalıştıkları sözcüğün sonraki edinimlerine genelleyerek bozuk yapılar oluşturmalarının engellenmesi önlenmelidir. Bu bağlamda öğrenicilerin sözcük kullanım alanları ve işlevlerindeki eksik öğrenmelerinin önüne geçilmeli ve bunun için öğrenicilere bol örnekler sunularak, sözcükler pekiştirmelidir. Bu noktada sözcük tekrar ve alıştırmaların öğrenicilerin işitsel ve görsel yetersizliklerini çözmede büyük bir yardımcı rol üsteleneceği aşikardır.

6. Günümüzde sözcük öğretimi, dilsel bir beceri olarak görülmekte ve bu beceri için sözcüğün doğru kullanımının güçlendirilmesi hedeflenmektedir. Elbette öğrenicinin sözcük dağarcığının genişlemesi; okuma, dinleme, yazma ve konuşma gibi becerileri üzerinde de olumlu bir etkiye sahiptir. Sözcük dağarcıklarının genişlemesi ve dilsel yapı bağlamında sözcüklerin doğru kullanımları adına yabancı dil öğretiminde kullanılagelen çeşitli tekniklerin yanı sıra öğreticilerin de sözcük öğretiminde hangi teknikler ve nasıl bir öğretim yöntemi izleyeceğini iyi bir şekilde belirlemesi gerekmektedir. Örneğin, başlangıç düzeyinde öğrenici hedef dilde yeni bir sözcük ile karşılaştığında, öğreticinin sözcüğün hedef dildeki kullanımı ve anlam karşılıklarını sunması sözcüğün öğreniminde etkili olabilmektedir. Sözcük öğretimi iki yöntem takip edilerek gerçekleştirilebilir. Bunlardan ilkinde, planlanmış etkinlikler yolu ile yani öğretici ve öğrenici belirli bir hedefi takip ederek, sözcük türleri ve sayılarının önceden belirlenmesi ile gerçekleştirilirken, ikinci yöntemde sözcük öğretimi için daha önceden herhangi bir plan yapılmamıştır ve öğretim ders sürecinde şekillenmektedir. Şöyle ki öğrenici bilmediği bir sözcüğün anlamını ders esnasında sorabilir ya da öğretici bir sözcüğü açıklamaya ihtiyaç duyduğunu fark eder ve öğretim bu yönde şekillenir. Planlanmış etkinlik türünde sözcük türü, öğretim yöntemini belirlemektedir. Bu öğretim yöntemine göre öğretici; tekrar, çeviri, görsellerden yararlanma, sözcük listesi gibi tekniklerden yararlanabilir.

7. Yabancı dil olarak Farsça öğreten öğreticilerin, öğrenicilerin hedef dil Farsçadaki sözcüklerin işlevselliği konusundaki kural kısıtlamalarını bilmemeleri sonucu yapmış oldukları aşırı genelleme ve seçme hatlarını göz önünde bulundurarak öğretim sürecinde kullanacakları materyaller ve ders içi etkinliklerinde Farsçanın sözvarlığını etkili ve belirli bir izlence içerisinde kullanmaları ve öğretimini yapacağı sözcükleri öğrenici düzeylerini göz önünde bulundurarak sinıflandırmaları önemlidir.

8. Türklere yabancı dil olarak Farsça öğretimi yapan öğreticilerin, yabancı dil öğretim sürecinde öğrenicilerin yazılı anlatım çıktılarını hata çözümlemesi ilkeleri doğrultusunda yazımsal, sözlüksel-anlamsal ve dilbilgisel özellikleri açısından tanımlaması önemlidir. Çetinkaya'nın da belirtmiş olduğu üzere, öğreticilerin öğrenicilerin yapmış oldukları hatalara nitelikli geribildirimler verebilmeleri için hataların özelliklerini tanımaları önemlidir. Çünkü 
öğretici, öğrenicilerin hatalarını düzeltip düzeltmeyeceğine, şayet düzeltecekse nasıl düzeltmesi gerektiğine sadece hatanın özelliklerini tanımlayıp kaynağına ulaştığında karar verebilir. ${ }^{30}$

9. Türkiye'de yabancı dil olarak Farsça öğrenen Türk öğrenicilerin dil gelişim sürecinde yapmış oldukları hatalar öğrenme süreci ve öğretici tekniklerine dair büyük öneme sahiptir. Çünkü öğrenicilerin yapmış oldukları bütün hatalar gerçek veri niteliği taşımakta ve öğrenicilere hedef dildeki genellemelerinin doğru olup olmadığı konusunda yol göstermektedir. Türkiye'de Farsça öğretim sürecinin amaca uygun bir biçimde ilerlemesi için öğrenicilerden elde edilen hata verilerinin materyal hazırlama sürecinde göz önünde bulundurulması gereklidir.

\footnotetext{
Hakem Değerlendirmesi: Dış bağımsız.

Çıkar Çatışması: Yazar çıkar çatışması bildirmemiştir.

Finansal Destek: Yazar bu çalışma için finansal destek almadığını beyan etmiştir.

Peer-review: Externally peer-reviewed.

Conflict of Interest: The author has no conflict of interest to declare.

Grant Support: The author declared that this study has received no financial support.
}

\section{Kaynakça/References}

Ahmedvend, A. "Teczîye ve Tahlîl-i Hatâhâ-yi Niviştârî-yi Fârsîamûzân-i Almânîzebân-i Sath-i Mukeddemâtî. Pâyânnâme-i Kârşinâsî-yi Erşed”. Tahran: Dânîşgâh-i Şehîd Bihiştî, 1389hş./2010.

Alevî Mukaddem, S. ve Hassâs Sadıkî, P. “Tahlîl-i Tavsîfî-yi Hatâhâ-yi Niviştârî-yi Fârsîâmûzân-i Arabzebânân”. Mecmûa-i Makâlât-i Nohomîn Hemâyişsi Zebânşinâsî̀-i İrân. Cild-i Dovvom, 1393hş./2014.

Alevî Mukaddem, S. ve Hayrâbâdî, M. “Tahlîl-i İsskâlât-i Niviştârî-yi Dânîşâmûzân-i İrânî-yi Gayri Fârsîzebân”. Faslnâme-i Novâverîhâ-i Amûzeşî. S.34, Y11:11, 1391hş./2012.

Büyükikiz, K. Kaan ve Hasırcı, Sevil. "Yabancı Dil Olarak Türkçe Öğrenen Öğrencilerin Yazılı Anlatımlarının Yanlış Çözümleme Yaklaşımına Göre Değerlendirilmesi”. Ana Dili Eğitim Dergisi. Say1:1(4), (2013), s. 51-62.

Büyüköztürk, Şener, Kılıç Çakmak Ebru, Akgün Özcan Erkan, Karadeniz Şirin ve Demirel Funda. Bilimsel Araştırma Yöntemleri (Gelişstirilmiş 11. Baskl). Ankara: Pegem Akademi, 2013.

Boylu, Emrah, Esma Zeynep Güney ve Kevser Esma Özyalçın. "Yanlış Çözümleme Yaklaşımına Göre Türkçeyi Yabancı Dil Olarak Öğrenen B1 Seviyesi Öğrencilerinin Yazılı Anlatımlarının Değerlendirilmesi”. International Journal of Languages Education and Teaching. Volume 5, Issue 3, September, (2017), s.184-202.

Bölükbaş, Fatma. “Arap Öğrencilerin Türkçe Yazılı Anlatım Becerilerinin Değerlendirilmesi”. Turkish Studies. 6/3, (2011). s.1357- 1367.

Corder, Stephen. "The Significance of Learners Error". International Review of Applied Linguistics. Volume:5, (1967), s. 161-170.

Çetinkaya, Gökhan. "Yanlış Çözümlemesi: Yabancı Dil Olarak Türkçe Öğrenen B2 Düzeyindeki Öğrencilerin Yazılı Metinlerine İlişkin Görünümler”. International Journal of Languages Education and Teaching. Volume 3/1 April (2015): 164-178.

30 Gökhan Çetinkaya, "Yanlış Çözümlemesi: Yabancı Dil Olarak Türkçe Öğrenen B2 Düzeyindeki Öğrencilerin Yazılı Metinlerine İlişsin Görünümler”, s.176. 
Demircan, Ömer. Yabancı Dil Öğretim Yöntemleri. İstanbul: Ekin Eğitim Yayıncılık, 1990.

Ellis, Rod. Second Language Acquisition. Oxford: Oxford University Press, 1997.

Gilledârî, Mohammad. "Tahlîl-i Hatâhâ-yi Niviştârî-yi Zebânâmûzân-i Gayr-i İrânî". Mecmûa-i Makâlât-i Semînâr-i Amûzeş-i Zebân-i Fârsî be Gayr-i Fârsizebânân. Tahran: Kânûn-i Zebân-i Fârsî, 1387hş./2008.

Hong, H. S. "Berresî-yi Hatâhâ-yi Nahvî-yi Vietnâmîzebân der Yâdgîrî-yi Zebân Fârsî”. Pâyânnâme-i Kârşinâsî-i Erşed. Tahran: Dânîşgâh-i Allame Tabâtabâî, 1389hş./2010.

İslâmî, M. "Berresî-yi Hatâhâ-yi Vajgânî der Niviştâr-i Rûsîzebânân-i Fârsîâmûz". Mecmûa-i Makâlât-i Nohomîn Hemâyiş-i Zebânşinâsî̀-i İrân. Cild-i Evvel, 1393hş./2014.

İşler, Emrullah. "Karşıtsal Çözümleme ve Arapça Öğretimi”. Nüsha. Yı1:2, Sayı:6, (2002), s.123-134.

Karasar, Nihat. Bilimsel Araştırma Yöntemi. Ankara: Nobel Yayın Dağıtım, 2010.

Keshavarz, Mohammed Hossein. Contrastive Analysis and Error Analysis. Tehran: Rahnama Puclications, 2012.

Kûşlîpûr, R. “Tahlîl-i Hatâhâ-yi Nahvî-yi Dânîşâmûzân-i Do Zebâne-i Turkmen-i Makta-i Râhnemâî der Nigâriş ve Kârbord-i Zebân-i Fârsî”. Pâyânnâme-i Kârşinâsî-i Erşed. Tahran: Dânîşgâh-i Allame Tabâtabâî, 1389 hş./2010.

Lado, Robert. Language Teaching: A Scientific Approach. McGraw-Hill, 1964.

Mîrdehkân, Mehînnâz. Âmûzeş-i Zebân-i Fârsî be Ûrdû Zebânân ve Zebân-i Ûrdû be Fârsîzebânân. Tahran: İntişârât-i Beynelmilelî-yi El-Hadî, 1380hş./2001.

Mîrdehkân, M., Ahmedvend, A. ve Huseynî Kârger, N. S. "Hatâhâ-yi Niviştâr-i Fârsîâmûzân-i Almânîzebân der Sath-i Mukeddemâtî: Hatâhâ-yi İmlâî-Vâcî”. Pejûheşnâme-i Âmûzeş-i Zebnân-i Fârsî be Gayri Fârsîzebân. Y11:3, S.1, 1393hş./2014. s. 91-116

Mîr İsmâilî, M. "Berresî-yi Hatâhâ-yi Zebânî der Niviştâr-i Fârsîâmûzân-i Mâzenderânîzebân ba Teveccuh be Sath-i Mutavassit-i Zebânâmûzî”. Pâyânnâme-i Kârşinâsî-i Erşed. Tahran: Dânîşgâh-i Allemeh Tabâtabâî, 1380hş./2001.

Mutevellîân Nâînî, R. ve Melkîân, R. “Tahlîl-i Hatâhâ-yi Nahvî-yi Fârsîâmûzân-i Urdûzebân”. Pejûheşnâme-i Âmûzeş-i Zebân-i Fârsî be Gayri Fârsîzebân. Y11:3, S.1, s. 31-64, 1393hş./2014.

Nevvâbî Kamserî, A. "Teczîye ve Tahlîl-i Hatâhâ-yi Niviştârî-yi Fârsîamûzân-i Arabzebân”. Pâyânnâme-i Kârşinâsî-i Erşed. Tahran: Dânîşgâh-i Allame Tabâtabâî, 1385hş./2006.

Richards, Jack C. A Non-Contrastive Approach to Error Analysis. San Fransisco: Tesol Convention, 1970. ED037721.pdf 11.10.2017 tarihinde erişilmiştir.

Sridhar, Shikaripur N. "Contrastive Analysis, Error Analysis and Interlanguage”. Reading English as a Second Language. Ed. Kenneth Croft. USA: Winthrop Publisher Inc., 1976, s. 258-281.

Vardar, Berke. Açıklamalı Dilbilim Terimleri Sözlüğü. İstanbul: Multilingual Yayınları, 2002.

Yılmaz, Fatih ve Derya Bircan. "Türkçe Öğretim Merkezinde Okuyan Yabancı Öğrencilerin Yazılı Kompozisyonlarının "Yanlış Çözümleme Yöntemi”ne Göre Değerlendirilmesi”. International Journal of Language Academy. Volume 3/1 Spring, (2015). s.113-126.

Ziahosseiny, Seid Mohammad. Contrastive Linguistics. Tehran: Islamic University Press, 1994. 
